\title{
Breeding to Improve Symbiotic Effectiveness of Legumes
}

\author{
Vladimir A. Zhukov, Oksana Y. Shtark, \\ Alexey Y. Borisov and Igor A. Tikhonovich \\ Additional information is available at the end of the chapter \\ http://dx.doi.org/10.5772/53003
}

\section{Introduction}

Symbioses with beneficial microorganisms constitute the universal and ecologically highly effective strategy of adaptation of plants towards nearly all types of environmental challenges. Representatives of many groups of fungi and bacteria participate in plant-microbial symbioses (PMS) wherein they can colonize the plant surfaces, tissues or intra-cellular compartments using two basic adaptive strategies: nutritional and defensive. Construction of niches for hosting the symbiotic microbes involves the complicated developmental programs implemented under the joint control by plant and microbial partners and based on the crossregulation of their genes.

Legume plants (family Fabaceae) are known to form symbioses with extremely broad range of beneficial soil microorganisms (BSM), representing examples of almost all plantmicrobe mutualistic systems. Different groups of beneficial microbes improve host mineral nutrition, acquisition of water, promote the plant development and offer protection from pathogens and pests. For ecology and agriculture, the most important beneficial legume symbioses are arbuscular mycorrhiza (AM) and root nodule (RN) symbiosis. These symbioses demonstrate high level of genetic and metabolic integrity, compared with other interactions of legumes with plant growth-promoting rhizosphere bacteria (PGPR) and/or beneficial endophytic bacteria.

High integrity of AM and RN symbioses implies highly specific mutual recognition of partners, formation of special complex symbiotic compartments and integration of partners' metabolic pathways. In the symbioses, legume plant plays a role of the organizing center of the system as it performs functions of coordination and regulation of all developmental processes. During 
last decade, a significant progress has been achieved in revealing the genetic bases of symbioses formation and functioning, so the knowledge of the plant genetic control over symbioses can effectively facilitate breeding new varieties of legumes that are needed for modern sustainable agriculture. In this chapter, we describe the present state of the developmental genetics of legume symbioses and depict the potential to organize the multi-component symbioses to be used for optimizing the broad spectrum of plant adaptive functions and to improve the sustainability of legume crop production.

\section{Mechanisms of positive effect of BSM on the environment and health and yield of the legume plant}

\subsection{Legume-rhizobia Root-Nodule (RN) symbiosis}

Leguminous plants are able to grow in the soil/substrate without any combined nitrogen due to the fixation of atmospheric nitrogen by symbiotic nodule bacteria (collectively called rhizobia). In collaboration with rhizobia, legumes make a large contribution to the global nitrogen balance in natural and agricultural ecosystems [1]. Nitrogen fixation occurs within special plant organs, root nodules (in some associations stem nodules are also formed). Development of these organs represents a well-organized process based on the tightly coordinated expression of specialized symbiotic plant and bacterial genes. The legume nodules provide an ecological niche for bacteria, as well as structure for metabolic/signal exchange between the partners and for the control of symbionts by the hosts [2].

Family Fabaceae contains 17000-19000 species divided between three sub-families (Caesalpinioideae, Mimosoideae and Papilionoideae) and more than 700 genera of world-wide distribution [3]. With a single exception (Parasponia: Ulmaceae), the ability for symbioses with rhizobia is restricted to Fabaceae, although in eight related dicotyledonous families (Rosid I clade) an ability to form nodules with the nitrogen-fixing actinomycete Frankia is known [4].

By contrast to legumes, their nitrogen-fixing microsymbionts do not constitute a taxonomically coherent group of organisms. The majority of rhizobia belong to the $\alpha$-proteobacteria assigned into the Rhizobiaceae family solely on the basis of their ability to nodulate the legumes (e.g. Azorhizobium, Bradyrhizobium, Mesorhizobium, Rhizobium, Sinorhizobium). Recently some $\beta$ proteobacteria (close to Burkholderia, Cupriavidus, Pseudomonas and Ralstonia) and even some $\gamma$-proteobacteria have been discovered that can form nitrogen-fixing nodules with the legumes [5]. All these bacteria vary enormously in their overall genome organization, location of "symbiotic" (sym) genes and their molecular organization and regulation [6, 7].

Root-nodule symbiosis is well known as highly specific plant-microbe interaction. According to the early surveys of symbiotic specificity [8], legumes were suggested to comprise a range of taxonomically restricted cross-inoculation groups within which the free cross inoculation occurs, while the species from different groups do not cross-inoculate. The best studied examples of this classification are represented by four cross-inoculation groups: "Trifolium - Rhizobium leguminosarum bv. trifolii", "Pisum, Vicia, Lathyrus, Lens - 
R. leguminosarum bv. viciae", "Galega - R. galegae", "Medicago, Melilotus, Trigonella - Sinorhizobium meliloti, S. medicae". However, it was demonstrated later $[9,10]$ that such strictly defined specificity is limited to the herbage papilionoid legumes growing in temperate zones and representing the "Galegoid complex".

The specificity of legume-rhizobia interactions is expressed just during the pre-infection stage when rhizobia recognize the roots of appropriate host plants and colonize their surfaces. The interaction starts when the root-excreted signals, in particular, flavonoids, activate the rhizobial nodulation genes (nod/nol/noe) [11]. These genes control the synthesis of lipochitooligosaccharidic (LCO) nodulation factors (Nod factors, NFs) which induce the early stages of RN symbiosis development [12-14]. NFs represent the unique group of bacterial signal molecules not known outside legume-rhizobia symbiosis. They are among the most potent developmental regulators: their effect is expressed at concentrations of $10^{-8}-10^{-12} \mathrm{M}$ only. The core structure of these molecules, common for all rhizobia species, consists of 3-6 residues of $\mathrm{N}$-acetylglucosamine and of a fatty acid (acyl) chain. The type of symbiotic specificity is dependent mainly on the chemical modifications in NF structures [11]. However, a sufficient role in the host specificity of RN symbiosis may also be implemented by the interactions between bacterial surface molecules (some polysaccharides and proteins) $[15,16]$ and the lectins located on the root hair surfaces [17].

The main enzyme of nitrogen fixation in nodules is a nitrogenase that has a complex structure $[18,19]$. Synthesis of nitrogenase (the enzyme catalysing reduction of $\mathrm{N}_{2}$ into $\mathrm{NH}_{4}^{+}$) and other proteins involved in nitrogen fixation is induced in bacterial cells after they differentiate into a specific form called bacteroids. Bacteroids are embedded into a membrane structure named symbiosome, which formation as well as bacteroid differentiation is induced by plant [20]. These symbiosomes are organelle-like units of plant cell responsible for nitrogen fixation [21, 22]. Peri-bacteroid membrane (PBM) that surrounds bacteroids is an active interface of RN symbiosis where exchange of metabolites between symbionts occurs [23].

A pronounced differentiation is typical for rhizobia-infected plant cells, such as an increase in internal membrane structures participating in the PBM formation and biosynthetic processes. Polyploidization and chromatin decondensation are typical for these cells correlating with an elevated transcription activity [24]. Biochemically plant cell differentiation is expressed as a de novo synthesis of many proteins including leghaemoglobin and nodule-specific isozymes of carbon and nitrogen metabolism [25]. Leghaemoglobin binds oxygen actively ensuring its transport towards symbiosomes (which are characterised by the intensive respiration necessary to support energy consuming nitrogen fixation) and microaerobic conditions inside the nodules (required for the nitrogenase activity). The carbon and nitrogen metabolic enzymes responsible for the energy supply to nitrogenase and for the assimilation of fixed nitrogen are nodule specific [26]. Organic nitrogenous compounds formed from $\mathrm{N}_{2}$ fixation are transported to the upper parts of the plant either as amides (mainly asparagine (Asn), but also glutamine (Gln)) or as ureides (allantoin and allantoate), so that legumes can be classified as amide or ureide exporters according to the compounds they use for the mobilization of fixed nitrogen [27].

Rhizobial cells also undergo differentiation, but its level varies in different legume species. The terminal bacteroid differentiation (when bacteroids increase their size and DNA content and 
lack the capacity to divide) is specific for legumes belonging to the inverted repeat-lacking clade (IRLC) such as Medicago, Pisum, or Trifolium, whereas bacteroids in the non-IRLC legumes, such as Lotus, show no sign of terminal differentiation as they maintain their normal bacterial size, genome content, and reproductive capacity [28]. The same rhizobia strains that form symbiosis with both IRLC and non-IRLC legumes have different bacteroid differentiation fates in the two legume types. It was demonstrated that in Medicago and probably in other IRLC legumes, the nodule-specific NCR peptides act as symbiotic plant effectors to direct the bacteroids into a terminally differentiated state [29]. Possibly, IRLC legumes use nodulespecific NCR peptides to dominate the endosymbionts: NCR peptides interfere with many aspects of the bacteroid metabolism to allow the efficiency of the nitrogen fixation process to be optimized, for example, by stimulation enlargement and polyploidization of bacteroids [30]. Also, the peptides could be part of a mechanism to avoid the "cheating" of rhizobia that could use host resources to accumulate carbon storage compounds instead of fixing nitrogen [29], which is often observed in the non-IRLC legumes but not in the IRLC [30].

It was also found that nodules where terminal bacteroid differentiation takes place are more efficient in terms of energy use. Oono and Denison [31] reported that legume species with terminal bacteroid differentiation (such as peas (Pisum sativum L.) and peanuts (Arachis hypogaea L.) invest less in nodule construction but have greater fixation efficiency when compared to species with reversible bacteroid differentiation (such as beans (Phaseolus vulgaris L.) and cow peas (Vigna unguiculata (L.) Walp.). This effect is probably due to genomic endoreduplication of the bacteroids and full contact of single undivided bacteroid with peribacteroid membrane (some reproductive bacteroids can lose contact with PBM after they divide). Still, this is not known if these useful features of terminal bacteroids differentiation in some legumes could be transferred into other legume species. In work of van de Velde et al. [29], expression of NCR genes in nodules of Lotus japonicus (Regel.) K. Larsen (with normally reversible bacteroid differentiation) was sufficient to induce bacteroid morphologies reminiscent of terminally differentiated bacteroids of Medicago truncatula Gaertn. But, no positive effect on nitrogen fixation efficiency was reported, probably because there are much more regulatory genes needed to make bacteroids work propertly in such a heterologous system.

\subsection{Arbuscular Mycorrhiza (AM)}

Arbuscular mycorrhiza (AM) is formed by at least $80 \%$ of contemporary terrestrial plants with fungi of phylum Glomeromycota. The Glomeromycota are unique as the only monophyletic mycorrhizal fungus lineage that has co-evolved with land plants throughout their history. They are obligate biotrophs that colonize plant roots obtaining photosynthates, such as carbohydrates (hexoses), and niches for both their growth and reproduction. The AM is evolved more than 400 million years ago and was considered to play a decisive role in plants achieving a terrestrial existence [32-34]. The AM is supposed to be "the mother of plant root endosymbioses" [35]. Since legumes originated long after AM, about 60 million years ago [36], it may be assumed that all of them have the potential to produce this type of symbioses. Lupinus is the only known genus where this ability had apparently been lost [37-39]. 
Specificity of AM symbiosis is relatively low [34]. Symbiosis establishment starts with molecular dialogue between the partners. Plant roots release sesquiterpenes (also known as inducers of parasitic plant seed germination) as well as different phenolic compounds, including flavonoids, which induce fungal hypha growth and branching [40, 41]. Similar to rhizobia, AM-fungi produce signal molecules termed Myc factors (mycorrhization factors) [42], which can be recognized by the plant. They are a mixture of several lipochitooligosaccarides, the structure of which is close to that of rhizobial Nod factors, but is presumably more universal for different plant-fungus combinations [43]. Both sesquiterpenes and Myc factors are released constitutively and in the absence of physical contact with symbiotic partner [44].

The AM-fungi penetrate the root to colonize inner cortical cells. Plant plays an active role in fungus hosting inside the root tissues using cellular mechanisms similar to those used during rhizobial invasion, such as nucleus reposition, cytoplasm aggregation, special cytoskeletal tunnel assembly and symbiotic membrane formation (reviewed in: [45]). A special intracellular compartment of AM providing tight metabolic exchange between the partners is arbuscule, which is highly branched fungal hypha surrounded by membrane of plant origin [34] similar to symbiosome of $\mathrm{RN}$ symbiosis [35, 46].

Inner-root and outer parts of mycelium remain bound with arbuscules and are a single continuum via which the fungus is able to translocate mineral nutrient and water from the soil into the root system [47]. Thus, well developed AM-symbiosis allows plant growing well in nutrient-poor and drought-affected soils, increases its resistance against pathogens and pests and heavy metals, and improves soil structure (see below).

Phosphorous $(\mathrm{P})$ is one of the mineral nutrients essential for the plant growth (constituting up to $0.2 \%$ of the dry weight of the plant cell) and development. It plays the diverse regulatory, structural, and energy transfer roles and consequently is required in significant amounts $[48,49]$. The plants can acquire soluble forms of phosphorous directly from soil through the plant specific phosphate transporters (PTs). The dominant available forms in soil (orthophosphate ions, $\mathrm{P}_{\mathrm{i}}$ ) are very poorly mobile because of the abundance of cations such as $\mathrm{Ca}^{2+}, \mathrm{Fe}^{3+}$ and $\mathrm{Al}^{3+}$ [50]. In such environments where inorganic phosphorous is the predominant form in soil, a range of root adaptations, most of them primarily involved in mobilization and assimilation of phosphorous, are described including plant dependence on arbuscular mycorrhizas (see for review: [34, 51]). In most cases there is a preferential uptake via fungal hyphae (the mycorrhizal uptake pathway) [52]. Studies employing radioactive tracers to track hyphal $P_{i}$ uptake from soil have shown considerable AM contributions to phosphorous uptake [53-55]. The process involves several fungal transport systems some of which have an extremely high affinity for $\mathrm{P}_{\mathrm{i}}[56]$.

After transporting into hyphae, the major part of $\mathrm{P}_{\mathrm{i}}$ is polymerized by polyphosphate kinase into polyphosphates (poly-P), the linear chains of $\mathrm{P}_{\mathrm{i}}$. The granules rich in poly-P together with phosphorous-containing esters are packed into the cylindrical vacuoles which are transported along the hyphae by tubulin fibrils. After reaching the arbuscules, phosphorous compounds are destroyed by phosphatases and the released $P_{i}$ cross the partners' interface [56-58]. The arbuscule is the site of phosphate transfer from fungus to plant. It is well documented that 
plants possess many classes of phosphate transport proteins, including those which are expressed only in AM symbiosis [59-61]. It was discovered that five plant and one fungal PT genes are consistently expressed inside the arbusculated cells [60]. A plant phosphate transporter MtPt4 was shown to be expressed specifically on the peri-arbuscular membrane in Medicago truncatula [62].

The mycorrhizal $\mathrm{P}_{\mathrm{i}}$ uptake pathway is controlled by the plant host. Many results suggest that the plant phosphorous status is a major regulator controlling induction/repression of plant PT genes at both the soil-root interface and the inner-root symbiotic interface [63-65]. It was shown that high phosphorous concentrations counteract the induction of the mycorrhizal $\mathrm{P}_{\mathrm{i}}$ transporter genes by phospholipid extracts from mycorrhizal roots containing the mycorrhiza signal lysophosphatidylcholine [65]. The efflux of $P_{i}$ probably occurs in coordination with its uptake and the fungus, on its side, might exert the control over the amount of $\mathrm{P}_{\mathrm{i}}$ delivered to the plant [66].

Although $\mathrm{P}_{\mathrm{i}}$ acquisition receives more attention, the important advances in investigations on nitrogen uptake by AM-fungi have been made in recent years. AM-fungi directly uptake ammonium $\left(\mathrm{NH}_{4}^{+}\right)$, nitrate and amino acids [67] with preference to $\mathrm{NH}_{4}^{+}$[68]. The first step in the nitrogen uptake requires the activity of specific transporters located at the interface between the soil and extraradical mycelium. A fungal transporter gene (GintAMT1) involved in the process and having high affinity with $\mathrm{NH}_{4}{ }^{+}$was characterized [68].

Inorganic nitrogen that was taken up by the extraradical mycelium should then be incorporated into the amino acids and translocated to the intraradical mycelium, mainly as arginine (Arg) since this is the predominant free amino acid in the external hyphae [69]. The glutamine synthetase/glutamate synthase (GS/GOGAT) cycle is possibly responsible for a subsequent $\mathrm{NH}_{4}{ }^{+}$assimilation in AM extraradical hyphae [70,71], although the involvement of glutamate dehydrogenase has not been experimentally excluded. Arg similar to Poly-P is stored and is translocated along hyphae in vacuoles and is later released to the plant apoplast [66].

A mycorrhizal-specific $\mathrm{NH}_{4}{ }^{+}$transporter $\operatorname{LjAMT2;2}$ has been revealed recently in transcriptomic analysis of Lotus japonicus roots upon colonization with Gigaspora margarita. The gene has been characterized as a high-affinity AMT belonging to the AMT2 subfamily. It is strongly up-regulated and exclusively expressed in the mycorrhizal roots, but not in the nodules, and transcripts have preferentially been located in the arbusculated cells [72].

The plants colonized by AM-fungi have been demonstrated to manifest an increased resistance to attack of some pathogenic microorganisms, such as fungi, nematodes, bacteria, phytoplasma, and plant viruses (reviewed in: [73]) as well as to plant feeding insects $[74,75]$. However, it is still unknown whether such increased resistance to pathogens is a consequence of improved plant overall fitness or it is due to the specific defense responses induced by AM-fungi.

Actually, a range of processes occurring as a result of pathogen invasion (plant defense responses) also takes place in mycorrhized root tissues. They include the signal perception, signal transduction and defense-related gene activation [76-80]. The elements of hypersensitive responses have been observed to take place at both compatible and non- 
compatible combinations of plants with AM-fungi; reactions similar to the "oxidative burst" are typical for AM during fungus penetration into the epidermal cell [81]. In AM, as in other compatible biotrophic interactions, the defense-like response appears to be weak and occurs transitorily during the early phases of colonization, suggesting that the suppression of plant defense responses by the fungal signals may contribute to successful, compatible AM fungal colonization [76, 82]. AM-fungi are known to alter both constitutive and induced defenses in foliar tissues [83-85].

Drought stress is a major agricultural constraint in the semi-arid tropics. In most cases symbiosis with AM-fungi has been shown to increase host plant growth rates during drought stress and plant resistance to drought. Several mechanisms explaining this phenomenon have been proposed: an influence of AM on plant hormone profiles, increasing intensity of gaseous exchange and photosynthesis in leaves, direct water transport via fungal hyphae from soil into the host plant, enhanced water uptake through improved hydraulic conductivity and increasing leaf conductance and photosynthetic activity, nitrate assimilation by fungal hyphae, enhanced activity of plant enzymes involved in defence against oxidative stress, plant osmosis regulation, and changes in cell-wall elasticity (reviewed in: [86-89]).

The AM fungal hyphae grow into the soil matrix and create conditions conducive to the formation of microaggregates and then their packing into macroaggregates due to production copious amounts of the glycoprotein glomalin [90, 91]. Through AM-fungi-mediated effects on soil structure, it seems logical to suggest that AM colonization of a soil might affect its moisture retention properties and, in turn, the behaviour of plants growing in the soil, particularly when it is relatively dry [88].

AM-fungi were found to play an important role in heavy metal detoxification and the establishment of vegetation in strongly polluted areas (see for review: [92]). Fungal strains isolated from old zinc wastes also decrease heavy metal uptake by plants growing on metal rich substrates, limiting the risk of increasing the levels of these elements in the food chain [93]. Phytoremediation of metal contaminated areas attracts the increasing interest as a cheaper alternative to chemical methods, more friendly for environment and nondestructive to soil biota. The effectiveness of the bioremediation techniques depends on the appropriate selection of both the plant and the fungal partners. Plants conventionally introduced in contaminated areas disappear relatively soon, while those appearing during natural succession are better adapted to harsh conditions. Much more stable are plants that appear on the wastes spontaneously, but, it takes a long time till they establish and form stable communities. Symbiotic partners selected on the basis of such research are often the best choice for future phytoremediation technologies [93-96]. Introduction of plants from xerothermic grasslands into the soils contaminated with industrial metal rich wastes is supposed to be a new solution for waste revegetation [97]. Further improvements can be obtained by optimization of diverse microbiota including various groups of rhizospheric bacteria and shoot endophytes [92].

\subsection{Associations of roots with Plant Growth-Promoting Rhizobacteria (PGPR)}

Plant Growth Promoting Rhizobacteria (PGPR) are the taxonomically diverse group including different bacteria (Arthrobacter, Azospirillum, Bacillus, Enterobacter, Pseudomonas, Paenibacillus, 
Streptomyces) and even some archaea [98]. The PGPR are inhabitants of soil in the vicinity of plant roots and are dependent on consuming root exudates. Many PGPR are able to attach to root surfaces and to AM and other fungal hyphae. The PGPR provide several benefits affecting the host plant either directly (due to mineral nutrient improvement and stimulation of root development) or indirectly (due to defence of plants from soil-borne pathogens and improving host tolerance to abiotic stresses).

Similar to rhizobia, Azospirillum possess nitrogenase and therefore is able to fix atmospheric nitrogen. In the early papers, plant growth promoting activity was attributed mainly to associative nitrogen fixation. A broad distribution of cereal-Azospirillum associations was identified (reviewed in: [99]). It was demonstrated later, however, that a partial role in these plant-PGPR associations was due to phytohormone auxin (indole-3acetic acid, IAA) synthesis [100] which improves the root growth and assimilatory capabilities and hence aids nitrogen uptake by plants. In spite of absence of the visible anatomic differentiation in root-Azospirillum associations, its development involves a range of molecular interactions some of which may be common to endosymbiotic associations with rhizobia. Moreover, there is a visible taxonomic relatedness between Azospirillum and Bradyrhizobium genera. Thus, azospirilla and those slow-growing rhizobia might originate from a common Azospirillum-like ancestor (see for review: [101, 102]).

Many PGPR are able to solubilize sparingly soluble phosphates, usually by releasing chelating organic acids. Phosphate solubilizing bacteria (PSB) have been identified, but their effectiveness in the soil-plant system is unclear. The ability of an inoculated PSB to supply phosphopous to plant may be limited, either because the compounds released by PSB to solubilize phosphate are rapidly degraded or because the solubilized phosphate is re-fixed before it reaches the root surface [103].

The best studied examples of bacteria providing efficient defense from phytopathogens are: Pseudomonas (P. fluorescens, P. chlororaphis, P. putida), Bacillus (B. cereus, B. subtilis) and some Serratia (e.g., S. marcescens) species. Many of these bacteria are capable of preventing attacks by pathogenic fungi, nematodes and bacteria [98, 104, 105]. Diverse mechanisms may be involved in host protection offered by PGPR.

The best studied mechanism is the competitive exclusion of pathogens often related to their direct suppression by the bacterial antibiotic substances: phenazine-1-carboxamide, 2,4diacetylphloroglucinol, kanosamine, oligomycin A, oomycin A, pyoluterin, pyrrolnitrin, xanthobaccin, zwittermycin A, volatile dyes (HCN) and cyclic lipopeptides [98, 104, 105].

An important mechanism for the suppression of pathogens by biocontrol microbes may result from competition for iron or other metals, that involves bacterial siderophores which may possess much greater affinities for ferric ions than those for fungal siderophores $[104,105]$. The value of siderophores in biocontrol effects under natural conditions is predominantly associated with their ability to induce forms of systemic resistance in plant $[98,106]$.

Competitive exclusion of pathogens by PGPR is best achieved when the bacteria exhibit high root-colonizing activity. Application of the technique of genetic labeling with Green Fluorescent Protein (GFP) suggested that these bacteria do not regularly colonize the root interiors, 
and only rarely they can be observed inside the outer root tissues [98]. Most PGPR cells are concentrated on the root surface where the micro-colonies [98, 104] or bio-films are formed [107]. Since the interactions of plants with root-associated bacteria are not specific, the bacteria will colonize the roots of a broad spectrum of hosts. Specificity of the defensive association may be expressed however, at the point when antimicrobial compounds are being synthesized and this does not always correlate with bacteria taxonomy; many strains of Bacillus and Pseudomonas which possess plant-protective properties have close relatives amongst phytopathogenic types [106, 108, 109].

Microscopic observations demonstrated that suppression of fungi may be correlated with bacterial attachment to pathogen hyphae. As a result of this attachment, some PGPR strains commence their biocontrol functions by behaving as hyper-parasites of pathogenic fungi. This suppression may be related to the production of bacterial enzymes which destroy the pathogen cell walls [104, 105, 110, 111].

Sometimes the biocontrol activities of PGPR do not correlate with intensive colonization of host roots and plant protection results from only a small number of bacteria cells. This occurs when PGPR inoculation induces the systemic resistance mechanisms that make the root nonaccessible by pathogens. Initially this effect of PGPR was called ISR (Induced Systemic Resistance) and was attributed exclusively to nonpathogenic systems [112]; SAR (Systemic Acquired Resistance) reactions, by contrast, were considered to be typical for the interactions with plant pathogens. Nevertheless, it was later found that the reactions of both types occur in either pathogen or nonpathogen systems and are distinguished by the nature of their endogenous elicitors (reviewed in: $[106,113]$ ). The conventional SAR reaction is characterized by an accumulation of salicylic acid as signal molecules and pathogenesis-related proteins (PRproteins), whereas ISR reaction is based on signal transduction pathways regulated by jasmonates and ethylene. The systemic defence responses of both types may be elicited exogenously by PGPR cells attached to the roots or penetrating their outer tissues. Some molecules produced by PGPR (cell wall and cyclic lipopolysaccharides, flagella components, exoenzymes, phytohormones, type III secretion system (TTSS) effectors, siderophores, salicylic acid, and toxins) may be perceived by the plant and elicit a defensive response [106].

It has been reported that PGPR which produce an enzyme which is involved in the catabolism of 1-aminocyclopropane-1-carboxylate (ACC) - the ACC deaminase, can lower ethylene concentration in a developing or stressed plant, protecting it against the deleterious effects of ethylene induced stress and facilitating the formation of longer roots [114, 115]. This demonstrates that ethylene is negative regulator of plant interaction with PGPR.

Despite relatively low specificity of plant associations with PGPR, plant genotype has been shown to influence their effectiveness (i.e. genetic integration exists between the partners), and a series of genome loci (QTL) was identified controlling its quantitative variation [106, 116, 117]. The most pronounced plant species-specificity has been observed in the manifestation of ISR reactions caused by PGPR [118, 119].

Both highly effective direct promotion of plant growth and biocontrol may be due to an ability of the host to regulate PGPR functions by modulating the composition of root exudates. Root- 
excreted organic acids, but not sugars, are optimal for support of different types of PGPR [120-122]. Additionally, some plants (including the legumes, pea and alfalfa) regulate their PGPR functions by exudating specialised signals from the roots which mimic the bacterial "quorum sensing" regulators required for root colonization and antifungal activities [123]. These observations suggest that improvement of biocontrol functions in root-PGPR associations may be achieved via manipulations with the bacterial and plant host genotypes.

\subsection{Mutually beneficial associations of plants with endophytic bacteria}

Healthy naturally propagated plants grown in the field or in pot cultures are colonized by populations of endophytic bacteria. The spectrum of endophytic bacteria isolated from the roots of various plants covers a wide range of species; representatives of the genera Pseudomonas, Bacillus or Streptomyces are most frequently encountered as endophytes (reviewed in: [124]). Newly developed molecular methods enable complete analyses of the diversity of culturable and non-culturable bacteria [125]. Most of the known genera include some phytopathogenic endophytes. Endophytes and pathogens both possess many similar virulence factors (reviewed in: [124]).

Some endophytes are seed-borne, but others have mechanisms for colonizing plants that have yet to be elucidated [126]. Although there are occasional poorly substantiated reports of intracellular colonization of bacteria providing a consistent and effective increase in the productivity of crops, it is still considered that the intercellular apoplastic space is the most suitable niche for endophytes [127]. It is suggested that many bacterial 'endophytes' may not colonize the living tissues, but occupy protective niches in dead surface tissues or closely adhering soil of rhizosheaths. Consistent entry of endophytes into living root tissues in the field is supposed to require a bacterial capability to hydrolyse the hydrophobic incrustations of the walls of epidermal, hypodermal, endodermal, and other cortical cells [128].

Plant associations with endophytic bacteria can increase plant growth and promote general development or improve plant resistance to pathogens and other environmental stresses enhancing the host's ability to acquire nutrients, or by production of plant growth-regulating, allelopathic or antibiotic compounds [127, 129]. Sometimes improved plant resistance can be linked to induced systemic resistance caused by bacterial elicitors coming from the endophyte [130].

It is necessary to study the natural associations between bacterial endophytes and their hosts for the purposes of employing such systems most productively in sustainable agriculture [127]. Delivery of endophytes to the environment or agricultural fields should be carefully evaluated to avoid introducing plant, animal and human pathogens [131].

\subsection{Synergistic effect of microbes in rhizosphere}

Microorganisms in the rhizosphere are under the influence of root exudates and plant as a whole as well as of interspecies interactions with each other. Many fungi including AM-fungi can interact with different bacterial species which frequently attach to fungal mycelium (reviewed in: $[103,132,133])$. For those bacteria known to stimulate mycelial growth of 
mycorrhizal fungi and/or enhance root mycorrhization the term 'mycorrhiza-helper-bacteria' has been proposed $[133,134]$. Particularly, the bacteria may encourage growth of AM-fungi at the perisymbiotic stage of development, which precedes the establishment of a direct contact of the microsymbiont with the plant root $[103,135]$. On the other hand, AM-fungi directly modify the environment due to mycelial exudation [136], forming the so-called 'mycorrhizosphere' [137]. In addition, the stimulation of root exudation as a result of interactions with AMfungi leads to qualitative and quantitative changes of the bacterial community in the rhizosphere (reviewed in: [103, 132]).

Synergistic effect between RN and AM symbioses of legumes was described by many authors [95, 138-142]. AM formation is known to promote nodule development and nitrogen fixation by rhizobia, in particular, by means of improvement of mineral (predominantly phosphorous) host plant nutrition (see for review: [103]). AM-fungi also manifest synergism during interactions with PGPR (both indigenous and introduced), which perform biocontrol, nitrogen fixation, and phosphate mobilization during double and complex inoculation [103, 132]. The synergetic effect of plant inoculation by rhizobia and PGPR (Azospirillum, Bacillus, and Pseudomonas) is well known. In particular, it is associated with PGPR production of indole-3acetic acid, which encourages nodule formation [103, 143]. Triple inoculation of a model legume Anthyllis cytisoides with PGPR, AM-fungi and rhizobia was shown to be the most effective approach for revegetation in mediterranean semi-arid ecosystems [94].

Thus, the potential of microbial synergism allows us to speak about high prospects of biotechnologies focused on creation multicomponent symbioses (MCS) that increase the fertility and quality of agricultural legume and nonlegume crops. At the same time, the results of experiments with plant symbioses with AM-fungi, rhizobia and PGPR, including multimicrobial systems, show the important role of physiological and genetic adaptation of microorganisms to local environmental conditions $[92,94,95,144]$. Hence, during the development of such biotechnologies, it is recommended to use a complex of local microbial isolates adapted to particular environmental conditions.

\section{Plant genetic control over development and functioning of mutualistic symbioses of legumes}

\subsection{Legume genes involved in development of $\mathrm{RN}$ and AM symbioses}

The complex developmental processes which lead to the formation of intercellular and subcellular symbiotic compartments in RN and AM symbioses are controlled by both macro- and microsymbiont. Genetic systems of the symbionts are highly integrated, because some genes and gene products of one partner can switch certain genetic programs in another partner, still the development and function of the symbioses is reliant to the greatest extent on the plant. Developmental genetics of RNS is now well described because both plants and nodule bacteria can be subjected to genetic analysis during nitrogen-fixing nodule formation and functioning. There has been less investigation of AM systems. Mainly this is due to the difficulties encoun- 
tered in culturing AM-fungi, caused by their obligate symbiotic lifestyle and impossibility of using selective media. Additionally, genetic analysis of AM fungi is more complex because of their heterokaryotic nature and lack of sexual process [34, 145].

The plant genes involved in development of RN and AM symbioses may be divided into two groups, according to approach which was used for the gene identification. The first group, Sym genes [146], had been identified with the use of formal genetic analysis (started from selection of plant mutants defective in nodule development). The other group of genes comprises nodulins (from nodule) [147], mycorrhizins (from mycorrhiza) $[148,149]$, and symbiosins (from symbiosis) [149, 150]. These genes were identified by molecular genetic methods, through identification of proteins and/or RNAs synthesized de novo in root nodules (nodulins) or roots colonized by AM fungi (mycorrhizins). The genes whose expression is induced during the development of both endosymbioses, RNS and AM are called symbiosins [150].

Genes of these groups are suspected to play different roles in the processes which may be referred collectively as "management of microsymbionts" inside plant roots. Specifically, the products of some nodulin genes represent the structural elements of newly constructed temporary compartments developed during symbiosis [151]. The other nodulin genes may play essential roles in modulating the hormonal status of the developing nodules [152, 153]. Resently, in silico and microarray-based transcriptome profiling approaches have allowed identification of nodulins, mycorrhizins and symbiosins, which are being activated in response to an AM fungal signal, or by either rhizobial or AM fungal stimulus, respectively [149]. Several hundred genes were found to be activated at different stages of either symbiosis, with almost 100 genes being co-induced during nodulation and in AM formation. These co-induced genes representing the common evolutionary bases of AM and nodular symbioses can be associated with those cellular functions which are required for symbiotic efficiency, such as the facilitation of nutrient transport across the perisymbiotic membranes that surround the endosymbiotic bacteroids in root nodules and the arbuscules in AM roots [150]. However, it should be remembered that although most of the nodulins/mycorrhizins/symbiosins were already cloned and sequenced, functions for many of them have been identified only preliminary using the sequence data of the encoding genes and location of the gene products in the symbiotic compartments.

Still, most of nodulins, mycorrhizins and symbiosins seem to play a subordinate role in the regulatory scheme of symbiosis, nevertheless being indispensable for its functionality and stability. In turn, the major, regulatory role in realization of symbiotic programmes is to be assigned to Sym genes. These genes, in contrast to nodulin genes, are usually not expressed outside symbiotic structures and there are many examples of the high functional and sequence homologies between them in different legumes. First genes of this group had been identified using the spontaneous mutants from natural legume populations [154] and afterwards using the experimentally induced mutants defective in nodulation or nitrogen fixation $\left(\mathrm{Nod}^{-}\right.$and Fix- phenotypes) [155]. Afterwards, it was demonstrated that mutations in some of these genes also affect the ability of plant to form AM [148]. The presence of such common genes necessary for both $\mathrm{AM}$ and $\mathrm{RN}$ symbioses development suggested that both endosymbioses were more 
closely related than it was suspected before. The cloning and sequencing of the common symbiotic genes helped to understand that AM and RN symbioses share the overlapping signaling pathways, which probably were established during evolution the AM symbiosis and was recruited afterwards into the RN symbiosis development [35].

The large sizes of genomes of crop legumes (e.g. soybean Glycine max (L.) Merr. and pea) in which the formal genetics of symbioses was initially developed, as well as low capability for genetic transformation, complicate greatly the cloning of symbiotic genes, analysis of their primary structures and the gene manipulations. Therefore, in early 1990s the new legume species, Lotus japonicus [156] and Medicago truncatula $[157,158]$ have been introduced in studies as model plants. These species are characterized by small genomes (470 - 500 Mb; [159]) and can easily be genetically transformed [158, 160-162]. In addition, the short lifecycle and high seed productivity made them attractive and convenient model objects for studying molecular bases of RN and AM symbioses.

Genetic analysis in model legumes as well as in crop legumes was started with experimental mutagenesis. Large-scale programs of insertion, chemical and X-rays mutagenesis, performed by different research groups, resulted in generation of numerous symbiotic mutants in $L$. japonicus and $M$. truncatula $[163,164]$ which allowed researchers to identify and characterize a series of Sym genes. The genes involved at the initial stages of nitrogen-fixing symbiosis (early Sym genes) were of primary interest, allowing dissection of the mechanisms by which the NF signal is perceived and transduced by host plants [165]. It turned to be that after the perception of NF, the nodulation process follows the same signalling pathway as AM does, with slight differences, though.

\subsection{Common Symbiosis Pathway (CSP)}

The data obtained during the last fifteen years allowed reconstruction the symbiotic signaling pathway which starts in RN and AM symbioses with recognition the Nod and Myc factors, respectively, and goes on as the signal transduction inside the root. In legumes Nod and Myc factors are most likely perceived by specific receptor complexes [35]. The receptor for NF is considered to be a heterodimer composed of at least two LysM containing receptor kinases [166-168]. Alike, receptor for Myc factor (which is not known yet) also supposed to be consisted of similar receptor kinases, or even include one or more kinases participating in Nod factor signaling [169]. The system of receptor kinases perceiving signal molecules of microsymbionts seems to be complicated, with some receptor complexes being necessary not only for starting the interactions, but also on later stages, during penetration bacteria into the root cortex through root hair. Moreover, some receptor kinases could non-specifically bind Nod and Myc factors, which results in intensified growth of lateral roots [43, 169]. Probably, the diversity of receptor kinases should complement the variability of soil microorganisms and increase the specificity of interactions with mutually beneficial ones.

After the first step of reception of Nod or Myc factor, the symbiotic signal is being transmitted to the common pathway, named Common Symbiosis Pathway [170]. The first player in this pathway is LRR-receptor kinase, or SymRK (symbiotic receptor kinase), which is required for both RN and AM symbioses development [171, 172]. The ligand for this receptor kinase is not 
known yet. Interestingly, the activity of this kinase is also required for proper progression of late symbiotic stages, at least for rhizobial infection [173]. SymRK kinase domain has been shown to interact with 3-hydroxy-3-methylglutaryl CoA reductase 1 (HMGR1) from $M$. truncatula [174], and an ARID-type DNA-binding protein [175]. These results suggest that SymRK may form protein complex with key regulatory proteins of downstream cellular responses. Symbiotic Remorin 1 (SYMREM1) from M. truncatula and SymRK-interacting E3 ligase (SIE3) from L. japonicus have also been shown to interact with SymRK $[176,177]$.

The symbiosis receptor kinase SymRK acts upstream of the Nod and Myc factor-induced $\mathrm{Ca}^{2+}$ spiking in the perinuclear region of root hairs within a few minutes after NF application [178]. Perinuclear calcium spiking involves the release of calcium from a storage compartment (probably the nuclear envelope) through as-yet-unidentified calcium channels. To date it is known that the potassium-permeable channels might compensate for the resulting charge imbalance and could regulate the calcium channels in plants [179-183]. Also, nucleoporins NUP85 and NUP133 (to date described only in Lotus) are required for calcium spiking, although their mode of involvement is currently unknown. Probably, NUP85 and NUP133 might be a part of specific nuclear pore subcomplex that plays a crucial role in the signal process requiring interaction at the cell plasma membrane and at nuclear and plastid organellemembranes to induce a $\mathrm{Ca}^{2+}$ spiking $[184,185]$. Recently, the third constituent of a conserved subcomplex of the nuclear pore scaffold, NENA, was identified as indispensable component of AM and RN endosymbiotic development [186].

The calcium spiking is characteristic for both $\mathrm{RN}$ and AM symbioses formation [187]. These $\mathrm{Ca}^{2+}$ spikes are supposed to activate a calcium- and calmodulin-dependent protein kinase (CCaMK) that is also required for NF signaling and AM development [188]. This kinase contains an autoinhibition domain, removing of which leads to a spontaneous activation of downstream transcription events and induction of nodule formation in the absence of rhizobia [189]. Thus, CCaMK appears to be a general manager for both symbioses activating different cascades of signaling for $\mathrm{N}_{2}$-fixing symbiosis and $\mathrm{AM}$ in response to different $\mathrm{Ca}^{2+}$ spiking, because the next steps of nodulation signaling are independent from those of AM: the mutations in downstream Sym genes do not change the mycorrhizal phenotype of the legume. Interestingly, mutations in any Sym genes do not influence the defense reactions, suggesting that signaling pathways of mutualistic symbioses and pathogenesis are sufficiently different.

The calcium-calmodulin-dependent protein kinase (CCaMK) is supposed to be also involved in legume interactions with PGPR and/or endophytic bacteria as it was shown using inoculation of $M$. truncatula by $P$. fluorescens that MtDMI3 gene (encoding for CCaMK) regulates intercellular root colonization by bacteria as well as expression of some plant housekeeping genes known earlier as mycorrhizins [190].

The CCaMK is known to form a complex with CYCLOPS, a phosphorylation substrate, within the nucleus [35]. cyclops mutants of Lotus severely impair the infection process induced by the bacterial or fungal symbionts, and are also defective in arbuscule development [149]. During RNS, cyclops mutants exhibit the specific defects in infection-thread initiation, but not in the nodule organogenesis [191], indicating that CYCLOPS acts in an infection-specific branch of 
the symbiotic signaling network [35]. Cyclops encodes a protein with no overall sequence similarity to proteins with known function, but containing a functional nuclear localization signal and a carboxy-terminal coiled-coil domain.

It is supposed that CCaMK with help of CYCLOPS probably phosphorilates the specific transcription factors already present in cell: NSP1 and NSP2, which influence the changes of expression in several genes related to the symbiosis development [192, 193]. The activity of these proteins leads to the transcriptional changes in root tissues, for instance, increasing the level of early nodulins ENOD40, ENOD11, ENOD12, ENOD5, which are known to be the potential regulators of infection thread growth and nodule primordium formation [165, 194, 195). Also, the changes in cytokinin status of plant are detected, followed by up-regulation of genes encoding for RN symbiosis-specific cytokinin receptors [196-198]. Moreover, transcription regulators NIN and ERN are to be induced specifically downstream of the early NF signaling pathway in order to coordinate and regulate the correct temporal and spatial formation of root nodules [199-202].

The presented genes are responsible for the signal cascade which is aimed to induce the nodulin, mycorrhizin and symbiosin genes responsible for building the symbiotic structures and implementing their biochemical functions. It is supposed that the signaling pathway did not appear de novo in legumes when they become able to form nodules, but was developed from already existed system of AM formation into which the novel, nodule-specific genes were recruited. Still, new genes had been involved in RN symbiosis development, especially those encoding the receptors recognizing hormones (e.g. cytokinins) and hormone-like molecules (Nod factors).

\subsection{Autoregulation of symbioses formation}

Autoregulation of symbiosis development is an important process that takes place after successful mutual partners' recognition and signal exchange. For RN symbiosis, it is considered that legume host controls the root nodule numbers by sensing the external and internal cues. A major external cue is the soil nitrate, whereas a feedback regulatory system in which earlier formed nodules suppress further nodulation through shoot-root communication is an important internal cue. The latter is known as the autoregulation of nodulation (AON), and is believed to consist of two long-distance signals: a root-derived signal that is generated in infected roots and transmitted to the shoot; and a shoot-derived signal that inhibits nodulation systemically [203, 204]. Therefore, AON represents a strategy through which the host plant can balance the symbiotrophic $\mathrm{N}$ nutrition with the energetically more "cheap" combined N nutrition.

Recent findings on autoregulation of nodulation suggest that the root-derived ascending signals to the shoot are short peptides belonging to the CLE peptide family $[205,206]$. The leucine-rich repeat receptor-like kinase HAR1 of Lotus and its homologues in M. truncatula and P. sativum (SUNN and Sym29, respectively) mediate AON and also the nitrate inhibition of nodulation, presumably by recognizing the root-derived signal [207-210]. Other genes, like ASTRAY, KLAVIER and TML in Lotus, and RDN1 in M. truncatula, are also supposed to play a sufficient role in AON [211-214]. 
Very little is still known about the plant regulation of mycorrhization process. In split-root systems on alfalfa (Medicago sativa), inoculation of one half of a split-root system with the fungus Glomus mosseae significantly reduced later AM colonization on the other half. A similar suppressive effect on mycorrhization was observed after inoculation with Sinorhizobium meliloti [215]. Furthermore, prior addition of purifed rhizobial Nod factors on one half signifcantly reduced mycorrhization on the other half of the split-root system, and reciprocally, prior mycorrhization on one side suppressed nodule formation on the other side of the splitroot system. Together these data point to a common autoregulation circuit for both symbioses [210]. It was suggested that Nod factor signaling, as well as mycorrhizal Myc factor signaling, induces expression or post-translation processing of CLE peptides, which likely function as ascending long-distance signals to the shoot [210]. Also, it was demonstrated that mutations in HAR1 of Lotus and corresponding orthologues in other legumes increase both nodulation and mycorrhization suggesting the shared role of these orthologous genes in controlling the rate of root colonization by microsymbionts. Thereby, not only the local signal transduction (CSP) but the systemic autoregulation is common for the RN and AM symbioses.

\subsection{Next stage of development the genetics of symbioses}

The next-coming step of development the genetics of symbioses is studying gene networks on intergenomic level, i.e. the coordinated expression of plant and microbe genes. For AM, with use of the new molecular approaches, in particular transcriptomics, a series of AM fungal genes has been identified, having altered expression levels during the AM formation [216-219]. Still it is not well studied at which stages of fungal-plant interaction the complementary partners' genes are induced or repressed, and so the use of plant mutants impaired at different steps of AM development might be a challenging approach to reveal the pattern of plant and fungal genetic cooperation [220]. The same research aimed at identification of plant-rhizobial gene interactions with the use of plant and microbe mutants is also in progress.

It has been recently observed that Medicago truncatula showed significantly lower efficiency of nitrogen fixation than its close relative Medicago sativa L. [221]. The number of nodules formed on the roots of $M$. truncatula was less than that of $M$. sativa, and the nitrogen fixation measured on plants at the beginning of flowering (as well as specific $\mathrm{N}_{2}$ fixation $\left(\mu \mathrm{gN} \mathrm{h} \mathrm{h}^{-1} \mathrm{mg}_{\text {nodule }}{ }^{-1}\right)$ ) was significantly lower. The reasons for the low efficiency in nitrogen fixation were partially a result of low relative efficiency (electron allocated to $\mathrm{N}_{2}$ versus $\mathrm{H}^{+}$), and slow nitrogen export from nodules in $M$. truncatula when compared to $M$. sativa. This might be connected with a low malate concentration in the nodule tissue of M. truncatula, and thus insufficient carbon provision for asparagine formation (fixed nitrogen is to be added to malate to form asparagine) [221]. Therefore, Sulieman and Schulze [221] suggest that improvement the malate formation in M. truncatula nodules could help improving the effectiveness of nitrogen fixation.

According to these data, genes encoding for enzymes of malate synthesis should be good candidates for markers to be used as selection and breeding aimed at improvement of symbiotic properties in M. truncatula. But, in different species potential markers of symbiotic effectiveness could be found among genes of different functional groups. Our original data on sequencing alleles of symbiotic genes in pea (Pisum sativum) varieties with different symbiotic 
effectiveness suggest that polymorphism of genes belonging to CSP does not correspond to symbiotic properties of pea varieties analysed (Zhukov V.A., unpublished results). Perhaps, good candidates for markers of symbiotic effectiveness could be found during large-scale screening by transcriptome sequencing in different pea genotypes, which is now underway in our laboratory.

\section{New approaches of application of mutually beneficial plant-microbe systems in sustainable agriculture}

\subsection{Development of multicomponent inocula containing BSM}

An existence of plant genes [148, 150, 222] and their molecular products [223] common for both $\mathrm{AM}$ and RN symbioses led to a conclusion that system of legume symbiotic genes should be considered as a single whole, controlling the development of a tripartite symbiosis (legume plant + AM fungi + rhizobia). This fact along with the demonstration of synergistic activity in beneficial soil microbes (reviewed in: [103]) and a suggestion that plant genetic systems controling the development of $\mathrm{RN}$ and, probably, of some other beneficial plant-microbe associations evolved on the basis of that of AM [35] have great importance for the application of tripartite or even multi-partite symbiotic systems in low-input sustainable environmentallyfriendly agrotechnologies.

The use in sustainable agriculture of inocula based on beneficial soil microbes as described above allows the improvement crop productivity with decreased doses of mineral fertilizers and pesticides (reviewed in: [224, 225]). These days the majority of commercial inocula contain pure cultures of single microorganisms and only occasionally multiple combinations. There are several objections to the use of mono-inoculation. Firstly, endemic microbial communities are stable and the introduced microbe may be allowed to occupy a very small niche in the whole community or even get lost in a first week after introduction. Secondly, genetic material in microbes is very plastic, and consequently strains introduced into natural ecosystems can rapidly lose their beneficial traits. Thirdly, the existence of microbial cooperation in the rhizosphere [103] as well as in natural synergistic associations of different microbes including those between AM fungi and their endocellular or superficial symbionts [103, 132] question the possibility and expediency of applying mono-inoculants and even use of the term 'monoinoculation' itself. Finally, plants possess relatively stable genomes and this fact contributes significantly to the effectiveness of symbiosis [226]. Therefore, for industrial plant production in sustainable systems we should use plants having highly effective interactions with all kinds of beneficial soil microbes, which can encourage the development of multiple niches hosting microbes and regulating their activity. For this it is necessary to develop new multi-component microbial inocula which increase the content and biodiversity of beneficial soil microbes in agricultural land.

There is experimental evidence of the effectiveness of simultaneous inoculation of legumes with AM fungi and nodule bacteria leading to increased productivity and quality of the yield, 
e.g. groundnut [138], pea [139-141, 227], albaida (Anthyllis cytisoides) [95], and soybean [142]. The effect achieved equalled or exceeded that achieved with mineral fertilizers [140, 141, 227]. The effect also exceeded that of mono-inoculation with AM fungi or with rhizobia either in model experiments or under field conditions [139, 140, 142]. In long-term experiments in a desertified Mediterranean ecosystem, it was found that simultaneous inoculation with AM fungi and rhizobia enhanced the establishment of key plant species and increased soil fertility and quality; increased soil nitrogen content, organic matter content, and soil aggregate hydrostability and enhanced nitrogen transfer from nitrogen-fixing to non-fixing species associated with the natural succession of the plants [95].

There is an example of application of triple inoculum (AM fungi, rhizobia and PGPR) to the legume $A$. cytisoides which was successful only when the microorganisms used were isolated from local environment [94]. In collaboration with an innovation company "Bisolbi-Inter" (Russian Federation) the All-Russia Research Institute for Agricultural Microbiology (ARRIAM), Saint-Petersburg, Russian Federation, has developed technology for the production and application of a new multifunctional biopreparation BisolbiMix [228] containing a complex of the most effective isolates of endosymbiotic microbes (AM fungi and rhizobia) and associative bacteria (PGPR) from the collection held at ARRIAM. A non-sterile substratecarrier which is derived from washing-filtration by-products of a sugar-beet factory contains its own microbial community including all the above groups of beneficial microbes. The preparation can be formulated into a seed dressing (not effective for all the crop plants tested) or granules. The efficacy of BisolbiMix was demonstrated in field trials with legumes, e.g. pea [227] or non-legumes such as wheat, pumpkin and potato (Chebotar V.K. et al., unpublished results). The use of microbial formulations containing rhizobia for non-legumes seems to be sensible because it is known that nodule bacteria which do not form nodules on a non-host legume as well as non-legume roots can operate as PGPR [229, 230]. Thus, the selection of rhizobia with both PGPR activity and efficient symbiotic nitrogen fixation should be advantageous in crop rotations or intercropping systems using legumes and non-legumes.

It is possible, therefore, to develop effective multi-microbial inoculants, but it is necessary to use local communities of beneficial microbes because this exploits the natural biological and genetical adaptations of the partners to their environment [94, 231].

\subsection{Breeding for improving legume symbiotic effectiveness}

During development of plant-microbe systems for low-input sustainable ecologically friendly plant cultivation it is necessary to be guided by conclusions of EC experts about global productivity of legumes (http://www.grainlegumes.com/aep/; http://ec.europa.eu/research/ biosociety/food_quality/projects/002_en.html) for sustainable agriculture. The use of legumes in agriculture is leading to: improved soil fertility and increased diversity of crops and soil microbial communities; reductions in the use of non-renewable natural resources; decreased negative effects from intensive agrotechnologies on the natural environment due to decreased requirement for mineral fertilizers and pesticides and decreased production of animal protein and associated wastes; local production of pollution-free food and forage; and a more stable 
income for the agricultural producers. This is why it is necessary to breed legumes which have highly effective interactions with beneficial soil microbes.

For more than twenty five years the authors' laboratory has specialized in the genetics of plant-microbe interactions using pea (P. sativum L.) as a model plant. Our experience for improving the effectiveness of beneficial plant-microbe systems with pea is consequently given as an example. At the same time, the authors' team knows only single record of other activity of this nature: genetic variability of onion (Allium spp.) has been shown with respect to its responsiveness to AM fungi inoculation which indicate that onion breeding for improving efficacy of associations with AM fungi is possible [232]. The necessity for this sort of plant breeding is also considered, mainly with respect to the effectiveness of RN symbiosis [233-236].

\subsection{Analysis of genetic variability of pea with respect to its effectiveness of interactions with beneficial soil microbes}

A high level of genetic variability was demonstrated in analyses of the symbiotic effectiveness under double inoculation with AM fungi and nodule bacteria of 99 land-races and outclassed heritage cultivars of $P$. sativum from the collection N.I. Vavilov's All-Russia Research Institute of Plant Industry, Saint-Petersburg, Russian Federation, of different geographical origin [139, 141]. In a few genotypes considerable increases in plant dry weight (about $300 \%$ ), seed productivity (more than 650\%), phosphorus and nitrogen content (more than 900 and more than $300 \%$, respectively) were observed. The most promising highly symbiotically effective genotypes and those with low symbiotic potential were included in the Pea Genetic Collection (ARRIAM) to be used for experiments studying the functioning of tripartite/multipartite symbiosis. Types identified as highly symbiotically effective genotypes were involved in breeding programmes to create commercial pea cultivars with great potential for interactions with beneficial soil microbes (in collaboration with All-Russia Institute of Leguminous and Groat Crops (ARILGC), Orel, Russian Federation).

The most promising highly symbiotically effective pea genotypes previously selected and different commercial pea cultivars created without consideration of symbiotic effectiveness were involved in three-year field trials (Orel district) [227]. Seed productivity and plant dry weight were chosen as the main criteria for the evaluation of symbiosis effectiveness in legume crops. The double (actually multiple, see above comments on the nature of AM fungi) inoculation was shown to increase seed productivity and plant dry weight in most of the pea genotypes studied and sometimes this could exceed the effect of mineral fertilizers. The effectiveness of legume breeding to improve the symbiotic potential of legume cultivars was proven therefore under field conditions and the genotypes to be used in such breeding programmes were identified. The genotype K-8274 (non-commercial) was selected as a standard of symbiotic effectiveness. Additionally, it was demonstrated that highly effective genotypes can be also found among commercial pea cultivars created without consideration for effectiveness of interactions with beneficial soil microbes. Taking into account that most commercial legume cultivars have accidentally lost their abilities for symbiotrophic nutrition without selective pressure during breeding of intensive crops, the latter constitutes a very important finding for plant breeders 
and gives them the possibility for concurrent generation of cultivars with required pea plant architecture, other agriculturally important traits and high effectiveness of interactions with all types of beneficial soil microbes in a single breeding programme.

\subsection{Breeding to improve pea symbiotic effectiveness}

In order to cultivate plants with improved symbiotic potential a special breeding nursery was created in the experimental trials ground of ARILGC on land where for the 5 years before nursery establishment mineral fertilizers had not been applied. To reduce the incidence and severity of root pathogens a 6-field crop rotation was used where cultivation of winter wheat was followed by peas. The multi-component preparation BisolbiMix was used for the inoculation of test plants.

Using the breeding nursery as well as a breeding protocol developed from long-term collaboration of ARRIAM with ARILGC the first (in the whole history of legume breeding) pea cultivar "Triumph" having increased potential of interactions with beneficial soil microbes was intentionally created [237]. It arose as a result of crossing a commercial cultivar 'Classic' (donor of agriculturally important traits) and the genotype K-8274 (donor of symbiotic effectiveness trait) and subsequent individual selection of genotypes with high productivity and capacity for supporting various beneficial microbes.

The cultivar "Triumph" is of middle stem height, semi-leafless and has stable productivity under different climate conditions, it is comparatively resistant to root rots and pests. Its productivity is not lower than those of the productivity standards for Orel district using the conventional production technologies and $10 \%$ greater in comparison with the standard cultivars when inoculated with BisolbiMix. As a result of two-year state trials (2007-2008) the productivity of "Triumph" was shown to be comparable with those of standard regional cultivars enabling recommendation for commercial cultivation in the Central region of Russian Federation (unpublished results). Thus, the innovative concept of the authors' research team for plant breeding (applicable not only for legumes, but also for non-legumes) is bearing its first fruits.

\section{Conclusions}

Intimate associations of beneficial soil microbes with the host plants described above in detail are applicable in sustainable crop production if taken either separately or in combination. Many authors are now recognizing the need for using the multi-microbial plant inoculants and the advantages of using the indigenous plants (or varieties of local breeding) and microbes.

The authors' team proposes its own concept which offers fundamentally new approaches to plant production. Firstly, it is necessary to consider plant genetic systems controlling interactions with different beneficial soil microbes in unison. Secondly, plants used as a component of this complex plant-microbe system controlling its effectiveness should be bred to improve the effectiveness of interactions with all types of beneficial soil microbes. Increases of plant biomass production due to plant-microbe symbiosis should be used as the main parameter for 
an evaluation of plant effectiveness in interactions with beneficial soil microbes. The plant production should be done with inoculation composed of multi-component microbial inocula consisting of AM fungi, rhizobia, PGPR and/or beneficial endophytic bacteria. Finally, taking into consideration the importance of legumes for global agriculture, greater emphasis should be placed on plant-microbial systems in the development of low-input agro-biotechnologies enabling wider cultivation of leguminous crops.

Molecular markers are considered to be a convenient tool to facilitate breeding via MAS (marker-assisted selection) approach. But, search for suitable markers that are associated with symbiotic effectiveness trait is rather complicated problem. To our knowledge, there was no direct link between sequences of symbiotic genes and symbiotic effectiveness, and there are only a few examples of successful use of QTL analysis in legumes to trace loci associated with some symbiotic traits in pea [238] and Lotus [239]. So there's a gap between molecular genetic bases of symbioses development, from one side, and effective functioning the symbiotic systems in field conditions, from the other side. In our opinion, substantial improvement of methods of molecular genetics and bioinformatics, such as next-generation sequencing and proteome analysis, could help to build a bridge between fundamental and applied science in this area, and to improve the sustainability of the legume crop production.

\section{Key words and abbreviations}

arbuscular mycorrhiza (AM),

beneficial soil microorganisms (BSM),

defense of plants from pathogens,

developmental genetics,

endophytic bacteria,

evolution of symbiosis,

Glomeromycota,

leguminous plants,

Lotus japonicus,

Medicago truncatula,

molecular genetics,

mutational analysis,

Nod factor (NF),

phosphate transporter (PT),

Pisum sativum, 
plant growth promoting rhizobacteria (PGPR),

plant-microbe symbioses (PMS),

root nodule (RN)

root nodule symbiosis (RNS),

root nodule bacteria (rhizobia),

signal interactions,

symbiosomes,

symbiotrophic plant nutrition,

sustainable agriculture,

systemic regulation

\section{Acknowledgements}

We thank Dr. Margarita A. Vishnyakova (N.I. Vavilov All-Russia Research Institute of Plant Industry, St-Petersburg, Russian Federation), Dr. Tatiana S. Naumkina (All-Russia Institute of Legumes and Groat Crops, Orel, Russian Federation) and Dr. Vladimir K. Chebotar ("BisolbiInter" Ltd., St-Petersburg, Russian Federation) for the long-term collaboration in the fields of legume breeding and microbial inocula development. We are also grateful to Victoria Semenova (Komarov Botanical Institute, St-Petersburg, Russian Federation) for critical reading the manuscript. This work was supported by the grants of RFBR (10-04-00961, 10-04-01146, 12-04-01867), Grant to support leading Russian science school (HIII-337.2012.4) and Governmental contracts for research with Ministry of Science and Education of Russian Federation (II1304, 16.512.11.2155, \#8109).

\section{Author details}

Vladimir A. Zhukov, Oksana Y. Shtark, Alexey Y. Borisov and Igor A. Tikhonovich

*Address all correspondence to: zhukoff01@yahoo.com

All-Russia Research Institute for Agricultural Microbiology, St.-Petersburg, Russia

\section{References}

[1] Vance CP. Symbiotic Nitrogen Fixation and Phosphorus Acquisition. Plant Nutrition in the World of Declining Renewable Resources. Plant Physiol 2001;127(2): 390-397. 
[2] Brewin NJ. Plant Cell Wall Remodeling in the Rhizobium-Legume Symbiosis. Crit Rev Plant Sci 2004;23: 1-24.

[3] Allen ON, Allen EK. The Leguminosae. A Source Book of Characteristics, Uses and Nodulation. Madison: The University of Wisconsin Press; 1981.

[4] Wall LG. The Actinorhizal Symbiosis. J Plant Growth Regul 2000;19(2): 167-182.

[5] Balachandar D, Raja P, Kumar K, Sundaram SP. Non-Rhizobial Nodulation in Legumes. Biotechnol Molec Biol Rev 2007;2(2): 49-57.

[6] Spaink HP, Kondorosi A, Hooykaas PJJ., editors. The Rhizobiaceae. Molecular Biology of Model Plant-Associated Bacteria. Dordrecht/Boston/London: Kluwer; 1998.

[7] MacLean AM, Finan T, Sadowsky MJ. Genomes of the Symbiotic Nitrogen-Fixing Bacteria of Legumes. Plant Physiol 2007;144(2): 615-622.

[8] Fred EB, Baldwin IL, McCoy E. Root Nodule Bacteria and Leguminous Plants. Madison: Univ Wisconsin Stud Sci; 1932.

[9] Provorov NA. The Interdependence between Taxonomy of Legumes and Specificity of Their Interaction with Rhizobia in Relation to Evolution of the Symbiosis. Symbiosis 1994;17: 183-200.

[10] Broughton WJ, Perret X. Genealogy of Legume-Rhizobium Symbiosis. Curr Opin Plant Biol 1999;2(4): 305-311.

[11] Ovtsyna AO, Staehelin C. Bacterial signals required for the Rhizobium-legume symbiosis. In: Pandalai SG. (ed) Recent Research Developments in Microbiology, Vol 7 (Part II). Trivandrum, India: Research Signpost; 2003. p631-648.

[12] Spaink HP. The Molecular Basis of Infection and Nodulation by Rhizobia: the Ins and Outs of Sympathogenesis. Ann Rev Phytopathol 1995;33: 345-368.

[13] Schultze M, Kondorosi A. Regulation of Symbiotic Root Nodule Development. Annu Rev Genet 1998;32: 33-57.

[14] D'Haeze W, Holsters M. Nod Factor Structures, Responses, and Perception During Initiation of Nodule Development. Glycobiology 2002;12(6): 79-105.

[15] Becker A, Pühler A. Production of Exopolysaccharides. In: Spaink HP, Kondorosi A, Hooykaas PJJ. (eds) The Rhizobiaceae. Molecular Biology of Model Plant-Associated Bacteria. Dordrecht/Boston/London: Kluwer; 1998. p87-118.

[16] Lugtenberg BJJ. Outer Membrane Proteins. In: Spaink HP, Kondorosi A, Hooykaas PJJ. (eds) The Rhizobiaceae. Molecular Biology of Model Plant-Associated Bacteria. Dordrecht/Boston/London: Kluwer; 1998. p45-53.

[17] Jones KM, Sharopova N, Lohar DP, Zhang JQ, VandenBosch KA, Walker GC. Differential Response of the Plant Medicago truncatula to its Symbiont Sinorhizobium meliloti or an Exopolysaccharide-Deficient Mutant. Proc Natl Acad Sci USA 2008;105(2): 704-709. 
[18] Hirsch AM. Developmental Biology of Legume Nodulation. New Phytol 1992;122: 211-237.

[19] Sprent JI. Nodulation in Legumes. Royal Botanical Gardens, Kew: Cromwell Press Ltd; 2001.

[20] Oke V, Long SR. Bacteroid Formation in the Rhizobium-Legume Symbiosis. Curr Opin Microbiol 1999;2(6): 641-646.

[21] Brewin NJ (1998) Tissue and Cell Invasion by Rhizobium: the Structure and Development of Infection Threads and Symbiosomes. In: Spaink HP, Kondorosi A, Hooykaas PJJ. (eds) The Rhizobiaceae. Molecular Biology of Model Plant-Associated Bacteria. Dordrecht/Boston/London: Kluwer; 1998. p417-429.

[22] Tsyganov VE, Voroshilova VA, Herrera-Cervera JA, Sanjuan-Pinilla JM, Borisov AY, Tikhonovich IA, Priefer UB, Olivares J, Sanjuan J. Developmental Down-Regulation of Rhizobial Genes as a Function of Symbiosome Differentiation in Symbiotic Root Nodules of Pisum sativum L. New Phytol 2003;159(2): 521-530.

[23] Mylona P, Pawlowski K, Bisseling T. Symbiotic Nitrogen Fixation. Plant Cell 1995;7(7): 869-885.

[24] Pawlowski K, Bisseling T. Rhizobial and Actinorhizal Symbioses: What Are the Shared Features? Plant Cell 1996;8(10): 1899-1913.

[25] Vance CP, Heichel GH. Carbon in $\mathrm{N}_{2}$ Fixation: Limitation or Exquisite Adaptation? Annu Rev Plant Physiol 1991;42: 373-392.

[26] Fedorova M, Tikhonovich IA, Vance CP. Expression of C-assimilating Enzymes in Pea (Pisum sativum L.) Root Nodules. In situ Localization in Effective Nodules. Plant Cell Environ 1999;22(10): 1249-1262.

[27] Schubert KR. Products of Biological Nitrogen Fixation in Higher Plants: Synthesis, Transport, and Metabolism. Annu Rev Plant Physiol 1986;37: 539-574.

[28] Mergaert P, Uchiumi T, Alunni B, Evanno G, Cheron A, Catrice O, Mausset AE, BarloyHubler F, Galibert F, Kondorosi A, Kondorosi E. Eukaryotic Control on Bacterial Cell Cycle and Differentiation in the Rhizobium-Legume Symbiosis. Proc Natl Acad Sci USA 2006;103(13): 5230-5235.

[29] Van de Velde W, Zehirov G, Szatmari A, Debreczeny M, Ishihara H, Kevei Z, Farkas A, Mikulass K, Nagy A, Tiricz H, Satiat-Jeunemaître B, Alunni B, Bourge M, Kucho K, Abe M, Kereszt A, Maroti G, Uchiumi T, Kondorosi E, Mergaert P. Plant Peptides Govern Terminal Differentiation of Bacteria in Symbiosis. Science 2010;327(5969): 1122-1126.

[30] Oono R, Denison RF, Kiers ET. Controlling the Reproductive Fate of Rhizobia: How Universal Are Legume Sanctions? New Phytol 2009;183(4): 967-979.

[31] Oono R, Denison RF. Comparing symbiotic Efficiency Between Swollen Versus Nonswollen Rhizobial Bacteroids. Plant Physiol 2010;154(3): 1541-1548. 
[32] Schüßler A, Schwarzott D, Walker C. A New Fungal Phylum, the Glomeromycota: Phylogeny and Evolution. Mycol Res 2001;105: 1413-1297.

[33] Brundrett MC Coevolution of Roots and Mycorrhizas of Land Plants. New Phytol 2002;154: 275-304.

[34] Smith SE, Read DJ. Mycorrhizal Symbiosis (3 $3^{\text {rd }}$ ed.). London: Academic Press; 2008.

[35] Parniske M. Arbuscular Mycorrhiza: the Mother of Plant Root Endosymbioses. Nat Rev Microbiol 2008;6(10): 763-775.

[36] Lavin M, Herendeen PS, Wojciechowski MF Evolutionary Rates Analysis of Leguminosae Implicates a Rapid Diversification of Lineages during the Tertiary. Syst Biol 2005;54: 574-594.

[37] Sprent JI. Evolving Ideas of Legume Evolution and Diversity: A Taxonomic Perspective on the Ocurrence of Nodulation. New Phytologist 2007;174: 11-25.

[38] Sprent J. Evolution and Diversity of Legume Symbiosis. In: Dilworth MJ, James EK, Sprent JI, Newton WE (eds) Nitrogen-Fixing Leguminous Symbioses. Dordrecht: Springer; 2008. P 363-394.

[39] Sprent JI, James EK. Legume Evolution: Where Do Nodules and Mycorrhizas Fit in? Plant Physiol 2007;144: 575-581.

[40] Akiyama K, Matsuzaki K, Hayashi H. Plant Sesquiterpenes Induce Hyphal Branching in Arbuscular Mycorrhizal Fungi. Nature 2005;435: 824-827.

[41] Nagahashi G, Douds DD, Ferhatoglu Y. Functional Categories of Root Exudate Compounds and their Relevance to AM Fungal Growth. In: Koltai H, Kapulnik Y (eds) Arbuscular Mycorrhizas: Physiology and Function. Dordrecht: Springer; 2010. P 33-56.

[42] Kosuta S, Chabaud M, Lougnon G, Gough C, Denarie J, Barker DG, Becard G. A Diffusible Factor From Arbuscular Mycorrhizal Fungi Induces Symbiosis-Specific Mtenod11 Expression in Roots of Medicago truncatula. Plant Physiol 2003;131: 952-962.

[43] Maillet F, Poinsot V, André O, Puech-Pagès V, Haouy A, Gueunier M, Cromer L, Giraudet D, Formey D, Niebel A, Martinez EA, Driguez H, Bécard G, Dénarié J. Fungal Lipochitooligosaccharide Symbiotic Signals in Arbuscular Mycorrhiza. Nature 2011;469(7328): 58-63.

[44] Navazio L, Moscatiello R, Genre A, Novero M, Baldan B, Bonfante P, Mariani P. A Diffusible Signal From Arbuscular Mycorrhizal Fungi Elicits a Transient Cytosolic Calcium Elevation in Host Plant Cells. Plant Physiol 2007;144: 673-681.

[45] Genre A, Bonfante P. The Making of Symbiotic Cells in Arbuscular Mycorrhizal Roots. In: Koltai H, Kapulnik Y (eds) Arbuscular Mycorrhizas: Physiology and Function. Dordrecht: Springer; 2010. P 57-81.

[46] Parniske M. The Lotus japonicus LjSym4 Gene is Required for the Successful Symbiotic Infection of Root Epidermal Cells. Molec Plant-Microbe Iinteract 2000;13: 1109-1120. 
[47] Genre A, Bonfante P. Building a Mycorrhiza Cell: How to Reach Compatibility Between Plants and Arbuscular Mycorrhizal Fungi. J Plant Interact 2005;1: 3-13

[48] Bieleski RL Phosphate Pools, Phosphate Transport and Phosphate Availability. Annu Rev Plant Physiol 1973;24: 225-252.

[49] Schachtman DP, Reid RJ, Ayling SM. Phosphorus Uptake by Plants: From Soil to Cell. Plant Physiol 1998;116: 447-453.

[50] Tinker PB, Nye PH. Solute Movement in the Rhizosphere. Oxford, UK: Oxford University Press; 2000.

[51] Neumann E, George E. Nutrient Uptake: The Arbuscular Mycorrhiza Fungal Symbiosis as a Plant Nutrient Acquisition Strategy In: Koltai H, Kapulnik Y (eds) Arbuscular Mycorrhizas: Physiology and Function. Dordrecht: Springer; 2010. P 137-167.

[52] Smith SE, Smith FA, Jakobsen I. Mycorrhizal Fungi Can Dominate Phosphate Supply to Plants Irrespective of Growth Responses. Plant Physiol 2003;133: 16-20

[53] Schweiger P, Jakobsen I. Laboratory and Field Methods for Measurement Of Hyphal Uptake of Nutrients in Soil. Plant Soil 2000;226: 237-244.

[54] Nielsen JS, Joner EJ, Declerck S, Olsson S, Jakobsen I. Phospho-Imaging as a Tool for Visualization and Noninvasive Measurement of P Transport Dynamics in Arbuscular Mycorrhizas. New Phytol 2002;154: 809-820.

[55] Rufyikiri G, Declerck S, Thiry Y. Comparison of 233U and 33P Uptake and Translocation by the Arbuscular Mycorrhizal Fungus Glomus intraradices in Root Organ Culture Conditions. Mycorrhiza 2004;14: 203-207.

[56] Ezawa T, Smith SE, Smith FA. P Metabolism and Transport in AM Fungi. Plant Soil 2002;244: 221-230.

[57] Ashford A. Tubular Vacuoles in Arbuscular Mycorrhizas. New Phytol 2002;54: 545547.

[58] Ezawa T, Cavagnaro TR, Smith SE, Smith FA, Ohtomo R. Rapid Accumulation of Polyphosphate in Extraradical Hyphae of an Arbuscular Mycorrhizal Fungus as Revealed by Histochemistry and a Polyphosphate Kinase/Luciferase System. New Phytol 2003;161: 387-392.

[59] Karandashov V, Bucher M. Symbiotic Phosphate Transport in Arbuscular Mycorrhizas. Trends Plant Sci 2005;10: 22-29.

[60] Balestrini R, Gomez-Ariza J, Lanfranco L, Bonfante P. Laser Microdissection Reveals that Transcripts for Five Plant and One Fungal Phosphate Transporter Genes are Contemporaneously Present in Arbusculated Cells. Molec Plant-Microbe Interact 2007;20: 1055-1062.

[61] Javot H, Pumplin N, Harrison MJ. Phosphate in the Arbuscular Mycorrhizal Symbiosis: Transport Properties and Regulatory Roles. Plant Cell Environ 2007;30: 310-322 
[62] Harrison MJ, Dewbre GR, Liu J. A Phosphate Transporter from Medicago truncatula Involved in the Acquisition of Phosphate Released by Arbuscular Mycorrhizal Fungi. Plant Cell 2002;14: 2413-2429.

[63] Maeda D, Ashida K, Iguchi K, Chechetka SA, Hijikata A, Okusako Y, Deguchi Y, Izui K, Hata S. Knockdown of an Arbuscular Mycorrhiza-Inducible Phosphate Transporter Gene of Lotus japonicus Suppresses Mutualistic Symbiosis. Plant Cell Physiol 2006;47: 807-817.

[64] Javot H, Penmetsa RV, Terzaghi N, Cook DR, Harrison MJ. A Medicago truncatula Phosphate Transporter Indispensable For The Arbuscular Mycorrhizal Symbiosis. Proc. Natl. Acad. Sci. USA 2007;104: 1720-1725.

[65] Nagy R, Drissner D, Amrhein N, Jakobsen I, Bucher M. Mycorrhizal Phosphate Uptake Pathway in Tomato Iis Phosphorusrepressible and Transcriptionally Regulated. New Phytol 2009;181: 950-959.

[66] Bonfante P, Balestrini R, Genre A, Lanfranco L. Establishment and Functioning Of Arbuscular Mycorrhizas. In: Deising H (ed) The Mycota V. Plant Relationship ( $2^{\text {nd }}$ ed.). Berlin, Heidelberg: Springer-Verlag; 2009. P 259-274.

[67] Hawkins HJ, Johansen A, George E. Uptake and Transport of Organic and Inorganic Nitrogen by Arbuscular Mycorrhizal Fungi. Plant Soil 2000;226: 275-285.

[68] Lopez-Pedrosa A, Gonzalez-Guerrero M, Valderas A, Azcon-Aguilar C, Ferrol N. GintAMTi Encodes a Functional High-Affinity Ammonium Transporter that is Expressed in the Extraradical Mycelium of Glomus intraradices. Fungal Genet Biol 2006;43: 102-110.

[69] Jin H, Pfeffer PE, Douds DD, Piotrowski E, Lammers PJ, Shachar-Hill Y. The Uptake, Metabolism, Transport and Transfer of Nitrogen in an Arbuscular Mycorrhizal Symbiosis. New Phytol 2005;168: 687-696.

[70] Johansen A, Finlay RD, Olsson PA. Nitrogen Metabolism of External Hyphae of the Arbuscular Mycorrhizal Fungus Glomus intraradices. New Phytol 1996;133: 705-712.

[71] Breuninger M, Trujillo CG, Serrano E, Fischer R, Requena N. Different Nitrogen Sources Modulate Activity but not Expression of Glutamine Synthetase in Arbuscular Mycorrhizal Fungi. Fungal Genet Biol 2004;41: 542-552.

[72] Guether M, Neuhauser B, Balestrini R, Dynowski M, Ludewig U, Bonfante P. A Mycorrhizal-Specific Ammonium Transporter from Lotus japonicus Acquires Nitrogen Released by Arbuscular Mycorrhizal Fungi. Plant Physiol 2009;150: 73-83.

[73] Akhtar MS, Siddiqui ZA. Arbuscular Mycorrhizal Fungi as Potential Bioprotectants Against Plant Pathogens. In: Siddiqu ZA et al (eds) Mycorrhizae: Sustainable Agriculture and Forestry. Dordrecht: Springer; 2008. P 61-97.

[74] Koricheva J, Gange AC, Jones T. Effects of Mycorrhizal Fungi on Insect Herbivores: a Metaanalysis. Ecology 2009;90: 2088-2097. 
[75] Currie AF, Murray PJ, Gange AC. Is a Specialist Root-Feeding Insect Affected by Arbuscular Mycorrhizal Fungi? Appl Soil Ecol 2011;47: 77-83.

[76] Harrison MJ. Molecular and Cellular Aspects of the Arbuscular Mycorrhizal Symbiosis. Ann Rev Plant Physiol Plant Mol Biol 1999;50: 361-389.

[77] Blilou I, Bueno P, Ocampo JA, Garcia-Garrido JM. Induction of Catalase And Ascorbate Peroxidase Activities in Tobacco Roots Inoculated with the Arbuscular Mycorrhizal Fungus Glomus mossea. Mycol Res 2000;104: 722-725.

[78] Blilou I, Ocampo JA, Garcia-Garrido JM. Resistance of Pea Roots to Endomycorrhizal Fungus or Rhizobium Correlates with Enhanced Levels of Endogenous Salicylic Acid. J Exp Bot 1999;50: 1663-1668.

[79] Lambais MR. Regulation of Plant Defence-Related Genes in Arbuscular Mycorrhizae. In: Podila GK, Douds DD (eds) Current Advances in Mycorrhizae research The American Phytopathological Society, Minnesota; 2000. P 45-59.

[80] Bonanomi A, Wiemken A, Boller T, Salzer P. Local Induction of a Mycorrhiza-Specific Class III Chitinase Gene in Cortical Root Cells of Medicago truncatula Containing Developing or Mature Arbuscules. Plant Biol 2001;3: 94-199.

[81] Salzer P, Corbiere H, Boller T. Hydrogen Peroxide Accumulation in Medicago Truncatula Roots Colonized by the Arbuscular Mycorrhiza-Forming Fungus Glomus mosseae. Planta 1999;208: 319-325.

[82] Garcia-Garrido JM, Ocampo JA. Regulation of the Plant Defence Response in Arbuscular Mycorrhizal Symbiosis. J Exp Bot 2002;53: 377-1386

[83] Liu J, Maldonado-Mendoza I, Lopez-Meyer M, Cheung F, Town CD, Harrison MJ. Arbuscular Mycorrhizal Symbiosis is Accompanied by Local and Systemic Alterations in Gene Expression and an Increase in Disease Resistance in the Shoots. Plant J 2007;50: 529-544.

[84] Bennett AE, Bever JD, Bowers MD. Arbuscular Mycorrhizal Fungal Species Suppress Inducible Plant Responses and Alter Defensive Strategies Following Herbivory. Oecologia 2009;160: 711-719.

[85] Kempel A, Schmidt AK, Brandl R, Schadler M. Support from the Underground: Induced Plant Resistance Depends on Arbuscular Mycorrhizal Fungi. Funct Ecol 2010;24: 293-300.

[86] Quilambo OA. The Vesicular-Arbuscular Mycorrhizal Symbiosis. African J Biotechnol 2003;2: 539-546.

[87] Augé RM. Water Relations, Drought and Vesicular-Arbuscular Mycorrhizal Symbiosis Mycorrhiza 2001;11: 3-42.

[88] Augé RM, Moore JL, Sylvia DM, Cho K. Mycorrhizal Promotion of Host Stomatal Conductance in Relation to Irradiance and Temperature. Mycorrhiza 2004;14: 85-92. 
[89] Ruiz-Lozano JM, Aroca R. Host Response to Osmotic Stresses: Stomatal Behaviour and Water Use Efficiency of Arbuscular Mycorrhizal Plants. In: Koltai H, Kapulnik Y (eds) Arbuscular Mycorrhizas: Physiology and Function. Dordrecht: Springer; 2010. P 239-256.

[90] Celik I, Ortas I, Kilic S. Effects of Compost, Mycorrhiza, Manure and Fertilizer on Some Physical Properties of a Chromoxerert Soil. Soil and Tillage Res 2004;78: 59-67.

[91] Rillig MC. Arbuscular Mycorrhizae, Glomalin and Soil Aggregation. Can J Soil Sci 2004;84: 355-363.

[92] Turnau K, Ryszka P, Wojtczak G. Metal Tolerant Mycorrhizal Plants: A Review from the Perspective on Industrial Waste in Temperate Region In: Koltai H, Kapulnik Y (eds) Arbuscular Mycorrhizas: Physiology and Function. Dordrecht: Springer; 2010. P 257-279.

[93] Ryszka P, Turnau K. Arbuscular Mycorrhiza of Introduced and Native Grasses Colonizing Zinc Wastes: Implications for Restoration Practices. Plant Soil 2007;298: 219-229.

[94] Requena N, Jimenez J, Toro M, Barea JM. Interactions Between Plant-Growth-Promoting Rhizobacteria (PGPR), Arbuscular Mycorrhizal Fungi and Rhizobium spp. in the Rhizosphere of Anthyllis cytisoides, a Model Legume for Revegetation in Mediterranean Semi-Arid Ecosystems. New Phytologist 1997;136(4): 667-677.

[95] Requena N, Perez-Solis E, Azcón-Aguilar C, Jeffries P, Barea JM. Management of Indigenous Plant-Microbe Symbioses Aids Restoration of Desertified Ecosystems. Appl Environ Microbiol 2001;67(2): 495-498.

[96] Turnau K, Orlowska E, Ryszka P, Zubek S, Anielska T, Gawronski S, Jurkiewicz A. Role of Mycorrhizal Fungi In Phytoremediation and Toxity Monitoring of Heavy Metal Rhich Industrial Wastes in Southern Poland. In: Twardowska I, Allen HE, Häggblom MM, Stefaniak S (eds) NATO Science Series. Soil and Water Pollution Monitoring, Protection and Remediation. Dordrecht: Springer; 2007;69: 533-551.

[97] Turnau K, Anielska T, Ryszka P, Gawroński S, Ostachowicz B, Jurkiewicz A. Establishment of Arbuscular Mycorrhizal Plants Originating from Xerothermic Grasslands on Heavy Metal Rich Industrial Wastes - New Solution for Waste Revegetation. Plant Soil 2008;305: 267-280.

[98] Bloemberg G, Lugtenberg BJJ. Molecular Basis of Plant Growth Promotion and Biocontrol by Rhizobacteria. Curr Opin Plant Biol 2001; 4: 343-350

[99] Dobereiner J Isolation and Identification of Root Associated Diazotrophs. Plant Soil 1988;110: 207-212.

[100] Costacurta A, Vanderleyden J. Synthesis of Phytohormones by Plant-Associated Bacteria. Crit Rev Microbiol 1995;21: 1-18. 
[101] Provorov NA, Vorobyov NI. Evolutionary Genetics of Plant-Microbe Symbioses. New York: NOVA Science Publishers; 2010.

[102] Shtark O., Provorov N., Mikić A., Borisov A., Ćupina B., Tikhonovich I. Legume Root Symbioses: Natural History and Prospects For Improvement. Ratarstvo i povrtarstvo (Field and Vegetable Crops Research) 2011;48: 291-304.

[103] Barea JM, Pozo MJ, Azcon R, Azcon-Aguilar C. Microbial Cooperation in the Rhizosphere. J Exp Botany 2005;56(417): 1761-1778.

[104] Haas D, Defago G. Biological Control of Soil-Borne Pathogens by Fluorescent Pseudomonads. Nature Rev Microbiol. AOP, doi:10.1038/nrmicro1129 (accessed 10 March 2005).

[105] Siddiqui ZA. PGPR: Prospective Biocontrol Agents of Plant Pathogens. In: Siddiqui ZA (ed) PGPR: Biocontrol and Biofertilization. Dordrecht: Springer; 2005. P 111-142.

[106] Preston GM Plant Perceptions of Plant Growth-Promoting Pseudomonas. Phil Trans R Soc Lond B 2004;359: 907-918.

[107] O'Toole GA, Kolter R. Initiation of Biofilm Formation in Pseudomonas fluorescens WCS365 Proceeds via Multiple, Convergent Signalling Pathways: a Genetic Analysis. Mol Microbiol 1998;28(3): 449-61.

[108] Stephens C, Murray W. Pathogen Evolution: How Good Bacteria go Bad. Curr Biol 2001;11: 53-56.

[109] Catara V. Pseudomonas corrugata: Plant Pathogen and/or Biological Resource? Mol Plant Pathol 2007;8: 233-244.

[110] Bolwerk A, Lagopodi AL, Wijfjes AHM, Lamers GEM, Lugtenberg BJJ, Bloemberg GV. Interactions between Pseudomonas Biocontrol Strains and Fusarium oxysporum f.sp. radicis-lycopersici in the Tomato Rhizosphere. In: Tikhonovich IA, Lugtenberg BJJ Provorov NA (eds) Biology of Plant-Microbe Interactions. IS-MPMI, St.-Petersburg 2004;4: 323-326.

[111] Popova EV, Khatskevich LK. In: Tikhonovich IA, Lugtenberg BJJ Provorov NA (eds) Biology of Plant-Microbe Interactions. IS-MPMI, St.-Petersburg 2004;4: 315-318.

[112] Van Loon LC, Bakker PA, Pieterse CMJ. Systemic Resistance Induced by Rhizosphere Bacteria. Annu Rev Phytopathol 1998;36: 453-483.

[113] Vallad E, Goodman RM. Systemic Acquired Resistance and Induced Systemic Resistance in Conventional Agriculture. Crop Sci 2004;44: 1920-1934.

[114] Penrose DM, Glick BR. Methods for Isolating and Characterizing ACC DeaminaseContaining Plant Growth-Promoting Rhizobacteria. Physiol Plantarum 2003;118: 10-15.

[115] Glick BR. The Role of Bacterial ACC Deaminase in Promoting the Plant Growth. In: Tikhonovich IA, Lugtenberg BJJ Provorov NA (eds) Biology of Plant-Microbe Interactions. IS-MPMI, St.-Petersburg 2004;4: 557-560. 
[116] Wu P, Zang G, Ladha JK, McCouch SR, Huang N. Molecular-Marker-Facilitated Investigation on the Ability to Stimulate $\mathrm{N}_{2}$ Fixation in the Rhizosphere by the Irrigated Rice Plants. Theor Appl Genet 1995;91: 1177-1183.

[117] Smith KP, Goodman RM. Host Variation for Interactions with Beneficial PlantAssociated Microbes. Annu Rev Phytopathol 1999;37: 473-491.

[118] Liu L, Kloepper JW, Tuzun S. Induction of Systemic Resistance in Cucumber by Plant Growth-Promoting Rhizobacteria: Duration of Protection and Root Colonization. Phytopathol 1995;85: 1064-1068.

[119] Van Wees SCM, Pieterse CMJ, Trijssenaar A, van Westende TAM, Hartog F, van Loon LC. Differential Induction of Systemic Resistance in Arabidopsis by Biocontrol Bacteria. Mol Plant-Microbe Interact 1997;10: 716-724.

[120] Kravchenko LV, Leonova EI. Use of Tryptophane from Root Exometabolites for Biosynthesis of Indolil-3-Acetic Acid by the Root-Associated Bacteria. Russian J Microbiol 1993;62: 453-459.

[121] Shtark OY, Shaposhnikov AI, Kravchenko LV. The Production of Antifungal Metabolites by Pseudomonas chlororaphis Grown on Different Nutrient Sources. Russian J Microbiol 2003;72(5): 574-578.

[122] Kamilova F, Kravchenko LV, Shaposhnikov AI, Makarova N, Lugtenberg B. Effect of Tomato Pathogen Fusarium oxysporum f. sp. radicis-lycopersici and Biocontrol Bacterium Pseudomonas fluorescens WCS635 on the Composition of Organic Acids and Sugars in Tomato Root Exudates. Mol. Plant-Microbe Interact 2006;19: 1121-1126.

[123] Teplitski M, Robinson JB, Bauer WD. Plants Secrete Substances that mimic Bacterial NAcyl Homoserine Lactone Signal Activities and Affect Population Density-Dependent Behaviors in Associated Bacteria. Mol Plant-Microbe Interact 2000;13: 637-648.

[124] Hallmann J, Berg G. Spectrum and Population Dynamics of Bacterial Root Endophytes. In: Schulz B, Boyle S, Sieber T (eds) Microbial Root Endophytes. Dordrecht: Springer; 2006. P 15-32.

[125] Van Overbeek LS, van Vuurde J, van Elsas JD. Application of Molecular Fingerprinting Techniques to Explore the Diversity of Bacterial Endophytic Communities. In: Schulz B, Boyle S, Sieber T (eds) Microbial Root Endophytes. Dordrecht: Springer; 2006. P 337-354.

[126] Schulz B, Boyle S, Sieber T. What are Endophytes? In: Schulz B, Boyle S, Sieber T (eds) Microbial Root Endophytes. Dordrecht: Springer; 2006. P 1-14.

[127] Sturz AV, Christie BR, Nowak J. Bacterial Endophytes: Potential Role in Developing Sustainable Systems of Crop Production. Cr Rev Plant Sci 2000;19(1): 1-30.

[128] McCully ME Niches for Bacterial Endophytes in Crop Plants: a Plant Biologists's View. Aust J Plant Physiol 2001;28: 983-990. 
[129] Berg G, Hallmann J. Control of Plant Pathogenic Fungi with Bacterial Endophytes. In: Schulz B, Boyle S, Sieber T (eds) Microbial Root Endophytes. Dordrecht: Springer; 2006. P 53-70.

[130] Kloepper JW, Ryu CM. Bacterial Endophytes as Elicitors of Induced Systemic Resistance. In: Schulz B, Boyle S, Sieber T (eds) Microbial Root Endophytes. Dordrecht: Springer; 2006. P 33-52.

[131] Rosenblueth M, Martinez-Romero E. Bacterial Endophytes and their Interactions with Hosts. Mol Plant-Microbe Interact 2006;19: 827-837.

[132] Artursson V, Finlay RD, Jansson JK. Interactions between Arbuscular Mycorrhizal Fungi and Bacteria and Their Potential for Stimulating Plant Growth. Environ Microbiol 2006;8(1): 1-10.

[133] Frey-Klett P, Garbaye J, Tarkka M. The Mycorrhiza Helper Bacteria Revisited. New Phytol 2007;176: 22-36.

[134] Garbaye J. Helper Bacteria: a New Dimension to the Mycorrhizal Symbiosis. New Phytol 1994;128: 197-210.

[135] Hildebrandt U, Ouziad F, Marner FJ, Bothe H. The Bacterium Paenibacillus validus Stimulates Growth of the Arbuscular Mycorrhizal fungus Glomus intraradices up to the formation of Fertile Spores. FEMS Microbiol Lett 2006;254: 258-267.

[136] Toljander JF, Lindahl BD, Paul LR, Elfstrand M, Finlay RD. Influence of Arbuscular Mycorrhizal Mycelial Exudates on soil Bacterial Growth and Community Structure. FEMS Microbiol Ecol 2007;61: 295-304.

[137] Rambelli A. The Rhizosphere of Mycorrhizae. In: Marks, G.L., and Koslowski, T.T. (eds) Ectomycorrhizae. New York, USA: Academic Press; 1973. P 299-343.

[138] Ibrahim KK, Arunachalam V, Rao PSK, Tilak KVBR. Seasonal Response of Groundnut Genotypes to Arbuscular Mycorrhiza - Bradyrhizobium Inoculation. Microbiol Res 1995;150: 218-224.

[139] Jacobi LM, Kukalev AS, Ushakov KV, Tsyganov VE, Provorov NA, Borisov AY, Tikhonovich IA. Genetic Variability of Garden Pea (Pisum sativum L.) for Symbiotic Capacities. Pisum Genetics 1999;31: 44-45.

[140] Borisov AY, Tsyganov VE, Shtark OY, Jacobi LM, Naumkina TS, Serdyuk VP, Vishnyakova MA. Pea (Symbiotic effectiveness). In: Tikhonovich IA, Vishnyakova MA. (eds) The Catalogue of World-Wide Collection. Issue 728. Saint Petersburg: VIR; 2002.

[141] Borisov AY, Shtark OY, Danilova TN, Tsyganov VE, Naumkina TS. Effectiviness of Combined Inoculation of Field Peas with Arbuscular Mycorrhizal Fungi and Nodule Bacteria. Russian Agricultural Sciences (Doklady Rossiiskoi Akademii Sel'skohozyaistvennykh Nauk) 2004;4: 5-7.

[142] Labutova NM, Polyakov AI, Lyakh VA, Gordon VL. Influence of Inoculation with Nodule Bacteria and Endomycorrhizal Fungus Glomus intraradices on Yield and Seed 
Protein and Oil Content of Different Soybean Cultivars. Russian Agricultural Sciences (Doklady Rossiiskoi Akademii Sel'skohozyaistvennykh Nauk) 2004;4(2): 2-4.

[143] Bakker PAHM, Raaijmakers JM, Bloemberg G et al (eds). New Perspectives and Approaches in Plant Growth-Promoting Rhizobacteria Research (Reprinted from Eur J Plant Pathol 2007;119(2)). Dordrecht: Springer; 2007.

[144] Andronov EE, Petrova SN, Chizhevskaya EP, Korostik EV, Akhtemova GA, Pinaev AG. Influence of Introducing the Genetically Modified Strain Sinorhizobium meliloti ACH-5 on the Structure of the Soil Microbial Community. Russian J Microbiol 2009;78( 4): 474-482.

[145] Pawlowska TE, Taylor JW. Organization of Genetic Variation in Individuals of Arbuscular Mycorrhizal Fungi. Nature 2004;427(6976): 733-737.

[146] Lie TA. Temperature-Dependent Root-Nodule Formation in Pea cv. Iran. Plant Soil 1971;34(3): 751-752.

[147] van Kammen A. Suggested Nomenclature for Plant Genes Involved in Nodulation and Symbiosis. Plant Mol Biol Rep 1984;2: 43-45.

[148] Gianinazzi-Pearson V. Plant Cell Responses to Arbuscular Mycorrhizal Fungi: Getting to the Roots of the Symbiosis. Plant Cell 1996;8(10): 1871-1883.

[149] Kistner C, Winzer T, Pitzschke A, Mulder L, Sato S, Kaneko T, Tabata S, Sandal N, Stougaard J, Webb KJ, Szczyglowski K, Parniske M. Seven Lotus japonicus Genes Required for Transcriptional Reprogramming of the Root During Fungal and Bacterial Symbiosis. Plant Cell 2005;17(8): 2217-2229.

[150] Küster H, Vieweg MF, Manthey K, Baier MC, Hohnjec N, Perlick AM. Identification and Expression Regulation of Symbiotically Activated Legume Genes. Phytochemistry 2007;68(1): 8-18.

[151] Albrecht C, Geurts R, Lapeyrie F, Bisseling T. Endomycorrhizae and Rhizobial Nod Factors Both Require SYM8 to Induce the Expression of the Early Nodulin Genes PsENOD5 and PsENOD12A. Plant J 1998;15(5): 605-614.

[152] Kumagai H, Kinoshita E, Ridge RW, Kouchi H. RNAi Knock-Down of ENOD40s Leads to Significant Suppression of Nodule Formation in Lotus japonicus. Plant Cell Physiol 2006;47(8): 1102-1111.

[153] Wan X, Hontelez J, Lillo A, Guarnerio C, van de Peut D, Fedorova E, Bisseling T, Franssen H. Medicago truncatula ENOD40-1 and ENOD40-2 Are Both Involved in Nodule Initiation and Bacteroid Development. J Exp Bot 2007;58(8): 2033-2041.

[154] Nutman PS. Genetical Factors Concerned in the Symbiosis of Clover and Nodule Bacteria. Nature 1946;157: 463-465.

[155] Jacobsen E. Modification of Symbiotic Interaction of Pea (Pisum sativum L.) and Rhizobium leguminosarum by Induced Mutations. Plant Soil 1984;82(3): 427-438. 
[156] Handberg K, Stougaard J. Lotus japonicus, an Autogamous, Diploid Legume Species for Classical and Molecular Genetics. Plant J 1992;2: 487-496.

[157] Barker D, Bianchi S, Blondon F, Dattee Y, Duc G, Essad S, Flament P, Gallusci P, Genier G, Guy P, Muel X, Tourneur J, Denarie J, Huguet T. Medicago truncatula, a Model Plant for Studying the Molecular Genetics of the Rhizobium-Legume Symbiosis. Plant Mol Biol Rep 1990;8: 40-49.

[158] Cook DR. Medicago truncatula - a Model in the Making. Curr Opin Plant Biol 1999;2(4): 301-304.

[159] Young ND, Mudge J, Ellis THN. Legume Genomes: More Than Peas in a Pod. Curr Opin Plant Biol 2003;6(2): 199-204.

[160] Cook DR, Vandenbosch K, de Brujin FJ, Huguet T. Model Legumes Get the Nod. Plant Cell 1997;9: 275-281.

[161] Udvardi MK. Legume Models Strut Their Stuff. Mol Plant Microbe Interact 2001;14(1): 6-9.

[162] Stougaard J. Genetics and Genomics of Root Symbiosis. Curr Opin Plant Biol 2001;4(4): 328-335.

[163] Penmetsa RV, Cook DR. A Legume Ethylene-Insensitive Mutant Hyperinfected By Its Rhizobial Symbiont. Science 1997;275(5299): 527-530.

[164] Schauser L, Handberg K, Sandal N, Stiller J, Thykjaer T, Pajuelo E, Nielsen A, Stougaard J. Symbiotic Mutants Deficient in Nodule Establishment Identified After T-DNA Transformation of Lotus japonicus. Mol Gen Genet 1998;259(4): 414-423.

[165] Albrecht C, Geurts R, Bisseling T. Legume Nodulation and Mycorrhizae Formation; Two Extremes in Host Specificity Meet. EMBO J 1999;18(2): 281-288.

[166] Radutoiu S, Madsen LH, Madsen EB, Felle HH, Umehara Y, Gronlund M, Sato S, Nakamura Y, Tabata S, Sandal N, Stougaard J. Plant Recognition of Symbiotic Bacteria Requires Two LysM Receptor-Like Kinases. Nature 2003;425(6958): 585-592.

[167] Madsen EB, Madsen LH, Radutoiu S, Olbryt M, Rakwalska M, Szczyglowski K, Sato S, Kaneko T, Tabata S, Sandal N, Stougaard J. A Receptor Kinase Gene of the LysM Type Is Involved in Legume Perception of Rhizobial Signals. Nature 2003;425(6958): 637-640.

[168] Limpens E, Franken C, Smit P, Willemse J, Bisseling T, Geurts R. LysM-domain Receptor Kinases Regulating Rhizobial Nod Factor-Induced Infection. Science 2003;302(5645):630-633.

[169] Op den Camp R, Streng A, De Mita S, Cao Q, Polone E, Liu W, Ammiraju JS, Kudrna D, Wing R, Untergasser A, Bisseling T, Geurts R. LysM-type Mycorrhizal Receptor Recruited for Rhizobium Symbiosis in Nonlegume Parasponia. Science 2011;331(6019): 909-912.

[170] Banba M, Gutjahr C, Miyao A, Hirochika H, Paszkowski U, Kouchi H, ImaizumiAnraku H. Divergence of Evolutionary Ways Among Common Sym Genes: CASTOR 
and CCaMK Show Functional Conservation Between Two Symbiosis Systems and Constitute the Root of a Common Signaling Pathway. Plant Cell Physiol 2008;49(11): 1659-1671.

[171] Endre G, Kereszt A, Kevei Z, Mihacea S, Kalo P, Kiss GB. A Receptor Kinase Gene Regulating Symbiotic Nodule Development. Nature 2002;417(6892): 962-966.

[172] Stracke S, Kistner C, Yoshida S, Mulder L, Sato S, Kaneko T, Tabata S, Sandal N, Stougaard J, Szczyglowski K, Parniske M. A Plant Receptor-Like Kinase Required for Both Bacterial and Fungal Symbiosis. Nature 2002;417(6892): 959-962.

[173] Limpens E, Mirabella R, Fedorova E, Franken C, Franssen H, Bisseling T, Geurts R. Formation of Organelle-Like $\mathrm{N}_{2}$-fixing Symbiosomes in Legume Root Nodules Is Controlled by DMI2. Proc Natl Acad Sci USA 2005; 102(29): 10375-10380.

[174] Kevei Z, Lougnon G, Mergaert P, Horvath GV, Kereszt A, Jayaraman D, Zaman N, Marcel F, Regulski K, Kiss GB, Kondorosi A, Endre G, Kondorosi, E-Ané JM. 3Hydroxy-3-methylglutaryl Coenzyme A Reductase 1 Interacts with NORK and Is Crucial for Nodulation in Medicago truncatula. Plant Cell 2007;19(12): 3974-3989.

[175] Zhu H, Chen T, Zhu M, Fang Q, Kang H, Hong Z, Zhang Z. A Novel ARID DNAbinding Protein Interacts with SymRK and Is Expressed During Early Nodule Development in Lotus japonicus. Plant Physiol 2008;148(1): 337-347.

[176] Lefebvre B, Timmers T, Mbengue M, Moreau S, Herve C, Tóth K, Bittencourt-Silvestre J, Klaus D, Deslandes L, Godiard L, Murray JD, Udvardi MK, Raffaele S, Mongrand S, Cullimore J, Gamas P, Niebel A, Ott T. A Remorin Protein Interacts with Symbiotic Receptors and Regulates Bacterial Infection. Proc Natl Acad Sci USA 2010;107(5): 2343-2348.

[177] Yuan S, Zhu H, Gou H, Fu W, Liu L, Chen T, Ke D, Kang H, Xie Q, Hong Z, Zhang Z. A Ubiquitin Ligase of Symbiosis Receptor Kinase Involved in Nodule Organogenesis. Plant Physiol 2012; DOI:10.1104/pp.112.199000.

[178] Wais RJ, Galera C, Oldroyd G, Catoira R, Penmetsa RV, Cook D, Gough C, Dénarié J, Long SR. Genetic Analysis of Calcium Spiking Responses in Nodulation Mutants of Medicago truncatula. Proc Natl Acad Sci USA 2000;97(24): 13407-13412.

[179] Ané JM, Kiss GB, Riely BK, Penmetsa RV, Oldroyd GE, Ayax C, Lévy J, Debellé F, Baek JM, Kalo P, Rosenberg C, Roe BA, Long SR, Dénarié J, Cook DR. Medicago truncatula DMI1 Required for Bacterial and Fungal Symbioses in Legumes. Science 2004;303(5662): 1364-1367.

[180] Imaizumi-Anraku H, Takeda N, Charpentier M, Perry J, Miwa H, Umehara Y, Kouchi H, Murakami Y, Mulder L, Vickers K, Pike J, Downie JA, Wang T, Sato S, Asamizu E, Tabata S, Yoshikawa M, Murooka Y, Wu GJ, Kawaguchi M, Kawasaki S, Parniske M, Hayashi M. Plastid Proteins Crucial for Symbiotic Fungal and Bacterial Entry into Plant Roots. Nature 2005;433(7025):527-531. 
[181] Edwards A, Heckmann AB, Yousafzai F, Duc G, Downie JA. Structural Implications of Mutations in the Pea SYM8 Symbiosis Gene, the DMI1 Ortholog, Encoding a Predicted Ion Channel. Mol Plant Microbe Interact 2007;20(10): 1183-1191.

[182] Riely BK, Lougnon G, Ané JM, Cook DR. The Symbiotic Ion Channel Homolog DMI1 Is Localized in the Nuclear Membrane of Medicago truncatula Roots. Plant J 2007;49(2): 208-216.

[183] Peiter E, Sun J, Heckmann AB, Venkateshwaran M, Riely BK, Otegui MS, Edwards A, Freshour G, Hahn MG, Cook DR, Sanders D, Oldroyd GE, Downie JA, Ané JM. The Medicago truncatula DMI1 Protein Modulates Cytosolic Calcium Signaling. Plant Physiol 2007;145(1): 192-203.

[184] Kanamori N, Madsen LH, Radutoiu S, Frantescu M, Quistgaard EMH, Miwa H, Downie JA, James EK, Felle HH, Haaning LL, Jensen TH, Sato S, Nakamura Y, Tabata $\mathrm{S}$, Sandal N, Stougaard J. A Nucleoporin Is Required for Induction of $\mathrm{Ca}^{2+}$ Spiking in Legume Nodule Development and Essential for Rhizobial and Fungal Symbiosis. Proc Natl Acad Sci USA 2006;103(2): 359-364.

[185] Saito K, Yoshikawa M, Yano K, Miwa H, Uchida H, Asamizu E, Sato S, Tabata S, Imaizumi-Anraku H, Umehara Y, Kouchi H, Murooka Y, Szczyglowski K, Downie JA, Parniske M, Hayashi M, Kawaguchi M. NUCLEOPORIN85 Is Required for Calcium Spiking, Fungal and Bacterial Symbioses, and Seed Production in Lotus japonicus. Plant Cell 2007;19(2): 610-624.

[186] Groth M, Takeda N, Perry J, Uchida H, Draxl S, Brachmann A, Sato S, Tabata S, Kawaguchi M, Wang TL, Parniske M. NENA, a Lotus japonicus Homolog of Sec13, is Required for Rhizodermal Infection by Arbuscular Mycorrhiza Fungi and Rhizobia But Dispensable for Cortical Endosymbiotic Development. Plant Cell 2010;22(7): 2509-2526.

[187] Oldroyd GE, Downie JA. Calcium, Kinases and Nodulation Signalling in Legumes. Nat Rev Mol Cell Biol 2004;5(7): 566-576.

[188] Catoira R, Galera C, de Billy F, Penmetsa RV, Journet EP, Maillet F, Rosenberg C, Cook D, Gough C, Denarie J. Four Genes of Medicago truncatula Controlling Components of a Nod Factor Transduction Pathway. Plant Cell 2000;12(9): 1647-1665.

[189] Gleason C, Chaudhuri S, Yang T, Munoz A, Poovaiah BW, Oldroyd GE. Nodulation Independent of Rhizobia Induced by a Calcium-Activated Kinase Lacking Autoinhibition. Nature 2006;441(7097): 1149-1152.

[190] Sanchez L, Weidmann S, Arnould C, Bernard AR, Gianinazzi S, Gianinazzi-Pearson V. Pseudomonas fluorescens and Glomus mosseae Trigger DMI3-Dependent Activation of Genes Related to a Signal Transduction Pathway in Roots of Medicago truncatula. Plant Physiol 2005;139(2): 1065-1077.

[191] Yano K, Yoshida S, Muller J, Singh S, Banba M, Vicker K. CYCLOPS, a Mediator of Symbiotic Intracellular Accommodation. Proc Natl Acad Sci USA 2008;105(51): 20540-20545. 
[192] Kaló P, Gleason C, Edwards A, Marsh J, Mitra RM, Hirsch S, Jakab J, Sims S, Long SR, Rogers J, Kiss GB, Downie JA, Oldroyd GE. Nodulation Signaling in Legumes Requires NSP2, a Member of the GRAS Family of Transcriptional Regulators. Science 2005;308(5729): 1786-1789.

[193] Smit P, Raedts J, Portyanko V, Debellé F, Gough C, Bisseling T, Geurts R. NSP1 of the GRAS Protein Family Is Essential for Rhizobial Nod Factor-Induced Transcription. Science 2005;308(5729): 1789-1791.

[194] Heckmann AB, Lombardo F, Miwa H, Perry JA, Bunnewell S, Parniske M, Wang TL, Downie JA. Lotus japonicus Nodulation Requires Two GRAS Domain Regulators, One of Which Is Functionally Conserved in a Non-Legume. Plant Physiol 2006;142(4): 1739-1750.

[195] Murakami Y, Miwa H, Imaizumi-Anraku H, Kouchi H, Downie JA, Kawasaki KMS. Positional cloning identifies Lotus japonicus NSP2, a Putative Transcription Factor of the GRAS Family, Required for NIN and ENOD40 Gene Expression in Nodule Initiation. DNA Res 2006;13: 255-265.

[196] Gonzalez-Rizzo S, Crespi M, Frugier F. The Medicago truncatula CRE1 Cytokinin Receptor Regulates Lateral Root Development and Early Symbiotic Interaction with Sinorhizobium meliloti. Plant Cell 2006;18(10): 2680-2693.

[197] Murray JD, Karas BJ, Sato S, Tabata S, Amyot L, Szczyglowski K. A Cytokinin Perception Mutant Colonized by Rhizobium in the Absence of Nodule Organogenesis. Science 2007;315(5808): 101-104.

[198] Tirichine L, Sandal N, Madsen LH, Radutoiu S, Albrektsen AS, Sato S, Asamizu E, Tabata S, Stougaard J. A Gain-of-Function Mutation in a Cytokinin Receptor Triggers Spontaneous Root Nodule Organogenesis. Science 2007;315(5808): 104-107.

[199] Schauser L, Roussis A, Stiller J, Stougaard J. A Plant Regulator Controlling Development of Symbiotic Root Nodules. Nature 1999;402(6758): 191-195.

[200] Borisov AY, Madsen LH, Tsyganov VE, Umehara Y, Voroshilova VA, Batagov AO, Sandal N, Mortensen A, Schauser L, Ellis N, Tikhonovich IA, Stougaard J. The Sym35 Gene Required for Root Nodule Development in Pea Is an Ortholog of Nin from Lotus japonicus. Plant Physiol 2003;131(3): 1009-1017.

[201] Marsh JF, Rakocevic A, Mitra RM, Brocard L, Sun J, Eschstruth A, Long SR, Schultze M, Ratet P, Oldroyd GE. Medicago truncatula NIN Is Essential for Rhizobial-Independent Nodule Organogenesis Induced by Autoactive Calcium/Calmodulin-Dependent Protein Kinase. Plant Physiol 2007;144(1): 324-335.

[202] Middleton PH, Jakab J, Penmetsa RV, Starker CG, Doll J, Kalo P, Prabhu R, Marsh JF, Mitra RM, Kereszt A, Dudas B, VandenBosch K, Long SR, Cook DR, Kiss GB, Oldroyd GE. An ERF Transcription Factor in Medicago truncatula That Is Essential for Nod Factor Signal Transduction. Plant Cell 2007;19(4): 1221-1234. 
[203] Caetano-Anolles G, Gresshoff PM. Plant Genetic Control of Nodulation. Annu Rev Microbiol 1991;45: 345-382.

[204] Ferguson BJ, Indrasumunar A, Hayashi S, Lin MH, Lin YH, Reid DE, Gresshoff PM. Molecular Analysis of Legume Nodule Development and Autoregulation. J Integr Plant Biol 2010;52(1): 61-76.

[205] Okamoto S, Ohnishi E, Sato S, Takahashi H, Nakazono M, Tabata S, Kawaguchi M. Nod Factor/Nitrate-Induced CLE Genes That Drive HAR1-Mediated Systemic Regulation of Nodulation. Plant Cell Physiol 2009;50(1): 67-77.

[206] Mortier V, Den Herder G, Whitford R, Van de Velde W, Rombauts S, D'Haeseleer K, Holsters M, Goormachtig S. CLE Peptides Control Medicago truncatula Nodulation Locally and Systemically. Plant Physiol 2010;153(1): 222-237.

[207] Krusell L, Madsen LH, Sato S, Aubert G, Genua A, Szczyglowski K, Duc G, Kaneko T, Tabata S,de Bruijn F, Pajuelo E, Sandal N, Stougaard J. Shoot Control of Root Development and Nodulation Is Mediated by a Receptor-Like Kinase. Nature 2002;420(6914): 422-426.

[208] Nishimura R, Hayashi M, Wu GJ, Kouchi H, Imaizumi-Anraku H, Murakami Y, Kawasaki S, Akao S, Ohmori M, Nagasawa M, Harada K, Kawaguchi M. HAR1 Mediates Systemic Regulation of Symbiotic Organ Development. Nature 2002;420(6914): 426-429.

[209] Schnabel E, Journet EP, de Carvalho-Niebel F, Duc G, Frugoli J. The Medicago truncatula SUNN Gene Encodes a CLV1-like leucine-Rich Repeat Receptor Kinase That Regulates Nodule Number and Root Length. Plant Mol Biol 2005;58(6):809-822.

[210] Staehelin C, Xie ZP, Illana A, Vierheilig H. Long-Distance Transport of Signals During Symbiosis: Are Nodule Formation and Mycorrhization Autoregulated in a Similar Way? Plant Signal Behav 2011;6(3): 372-377.

[211] Nishimura R, Ohmori M, Fujita H, Kawaguchi M. A Lotus Basic Leucine Zipper Protein with a RING-Finger Motif Negatively Regulates the Developmental Program of Nodulation. Proc Natl Acad Sci USA 2002;99(23): 15206-15210.

[212] Oka-Kira E, Tateno K, Miura K, Haga T, Hayashi M, Harada K, Sato S, Tabata S, Shikazono N, Tanaka A, Watanabe Y, Fukuhara I, Nagata T, Kawaguchi M. klavier (klv), a Novel Hypernodulation Mutant of Lotus japonicus Affected in Vascular Tissue Organization and Floral Induction. Plant J 2005;44(3): 505-515.

[213] Magori S, Oka-Kira E, Shibata S, Umehara Y, Kouchi H, Hase Y, Tanaka A, Sato S, Tabata S, Kawaguchi M. Too Much Love, a Root Regulator Associated with the LongDistance Control of Nodulation in Lotus japonicus. Mol Plant Microbe Interact 2009;22(3): 259-268.

[214] Schnabel EL, Kassaw TK, Smith LS, Marsh JF, Oldroyd GE, Long SR, Frugoli JA. The ROOT DETERMINED NODULATION1 Gene Regulates Nodule Number in Roots of 
Medicago truncatula and Defines a Highly Conserved, Uncharacterized Plant Gene Family. Plant Physiol 2011;157(1): 328-340.

[215] Catford JG, Staehelin C, Lerat S, Piché Y, Vierheilig H. Suppression of Arbuscular Mycorrhizal Colonization and Nodulation in Split-Root Systems of Alfalfa after PreInoculation and Treatment with Nod Factors. J Exp Bot 2003;54(386): 1481-1487.

[216] Grunwald U, Nyamsuren O, Tarnasloukht M, Lapopin L, Becker A, Mann P, Gianinazzi-Pearson V, Krajinski F, Franken P. Identification of Mycorrhiza-Regulated Genes with Arbuscule Development-Related Expression Profile. Plant Mol Biol 2004;55(4): 553-566.

[217] Gianinazzi-Pearson V, Brechenmacher L. Functional Genomics of Arbuscular Mycorrhiza: Decoding the Symbiotic Cell Programme. Canad J Bot 2004;82(8): 1228-1234.

[218] Seddas PMA, Arnould C, Tollot M, Arias CM, Gianinazzi-Pearson V. Spatial Monitoring of Gene Activity in Extraradical and Intraradical Developmental Stages of Arbuscular Mycorrhizal Fungi by Direct Fluorescent in situ RT-PCR. Fungal Gen Biol 2008;45(8): 1155-1165.

[219] Seddas PM, Arias CM, Arnould C, van Tuinen D, Godfroy O, Benhassou HA, Gouzy J, Morandi D, Dessaint F, Gianinazzi-Pearson V. Symbiosis-Related Plant Genes Modulate Molecular Responses in an Arbuscular Mycorrhizal Fungus During Early Root Interactions. Mol Plant Microbe Interact 2009;22(3): 341-351.

[220] Kuznetsova E, Seddas-Dozolme PM, Arnould C, Tollot M, van Tuinen D, Borisov A, Gianinazzi S, Gianinazzi-Pearson V. Symbiosis-Related Pea Genes Modulate Fungal and Plant Gene Expression During the Arbuscule Stage of Mycorrhiza with Glomus intraradices. Mycorrhiza 2010;20(6): 427-443.

[221] Sulieman S, Schulze J. The Efficiency of Nitrogen Fixation of the Model Legume Medicago truncatula (Jemalong A17) Is Low Compared to Medicago sativa. J Plant Physiol 2010;167(9): 683-692.

[222] Duc G, Trouvelot A, Gianinazzi-Pearson V, Gianinazzi S. First Report of Non-Mycorrhizal Plant Mutants (Myc) Obtained in Pea (Pisum sativum L.) and Faba Bean (Vicia faba L.). Plant Sci 1989;60(2): 215-222.

[223] Frühling M, Roussel H, Gianinazzi-Pearson V, Pühler A, Perlick AM. The Vicia faba Leghemoglobin Gene VfLb29 Is Induced in Root Nodules and in Roots Colonized by the Arbuscular Mycorrhizal Fungus Glomus fasciculatum. Mol Plant Microbe Interact 1997;10(1): 124-131.

[224] Xavier IJ, Holloway G, Leggett M Development of Rhizobial Inoculant Formulations. Crop Management (Online) 2004; doi:10.1094/CM-2004-0301-06-RV.

[225] Rai MK., editor. Handbook of microbial biofertilizers. New York: Haworth Press, Technology \& Engineering; 2006. 
[226] Tikhonovich IA, Provorov NA. Cooperation of Plants and Microorganisms: Getting Closer to the Genetic Construction of Sustainable Agro-Systems. Biotechnol J 2007;2(7): 833-848.

[227] Shtark OY, Danilova TN, Naumkina TS, Vasilchikov AG, Chebotar VK, Kazakov AE, Zhernakov AI, Nemankin TA, Prilepskaya NA, Borisov AY, Tikhonovich IA. Analysis of Pea (Pisum sativum L.) Source Material for Breeding of Cultivars with High Symbiotic Potential and Choice of Criteria for Its Evaluation. Ecological genetics ("Ekologicheskaja genetika") 2006;4(2): 22-28 (In Russian).

[228] Chebotar VK, Kazakov AE, Erofeev SV, Danilova TN, Naumkina TS, Shtark OY, Tikhonovich IA, Borisov AY. Method of Production of Complex Microbial Fertilizer. Patent No 2318784. 2008.

[229] Prévost D, Antoun H. Potential Use of Rhizobium as PGPR with Non-Legumes: Abstracts from the Inoculant Forum, March 17-18, 2005. Saskatoon, Saskatchewan, Canada.

[230] Hossain MS, Mårtensson A. Potential Use of Rhizobium spp. to Improve Fitness of NonNitrogen-Fixing Plants. Acta Agriculturae Scandinavica, Section B - Plant Soil Science 2008;58(4): 352-358.

[231] Gentili F, Jumpponen A. Potential and Possible Uses of Bacterial and Fungal Biofertilizers. In: Rai MK. (ed.) Handbook of Microbial Biofertilizers. New York: Haworth Press, Technology \& Engineering; 2006. p1-28.

[232] Galvan GA, Burger-Meijer K, Kuiper TW, Kik C, Scholten OE. Breeding for Improved Responsiveness to Arbuscular Mycorrhizal Fungi in Onion. Proceedings of 3rd International Congress of the European Integrated Project Quality Low Input Food (QLIF) Congress, Hohenheim, Germany, March 20-23, 2007. (Online) http:// orgprints.org/view/projects/int_conf_qlif2007.html

[233] Herridge D, Rose I. Breeding for Enhanced Nitrogen Fixation in Crop Legumes. Field Crops Res 2000;65: 229-248.

[234] Rengel Z. Breeding for Better Symbiosis. Plant Soil 2002;245(1): 147-162.

[235] Graham PH, Hungria M, Tlusty B. Breeding for Better Nitrogen Fixation in Grain Legumes: Where Do the Rhizobia Fit In? Crop Management 2004; doi:10.1094/ CM-2004-0301-02-RV.

[236] Howieson JG, Yates RJ, Foster KJ, Real D, Besier RB. Prospects for the Future Uses of Legumes. In: Dilworth MJ, James EK, Sprent JI, Newton WE. (eds) Nitrogen Fixing Leguminous Symbioses. Berlin/Heidelberg: Springer Science+Business Media BV; 2008. p363-394.

[237] Borisov AY, Danilova TN, Shtark OY, Solovov II, Kazakov AE, Naumkina TS, Vasilchikov AG, Chebotar VK, Tikhonovich IA. Tripartite Symbiotic System of Pea (Pisum sativum L.): Applications in Sustainable Agriculture. In: FD Dakora, BM Chimphango, 
AJ Valentine, C Elmerich, WE Newton (eds) Biological Nitrogen Fixation: Towards Poverty Alleviation Through Sustainable Agriculture. Proceedings of 15th International Congress on Nitrogen Fixation \& 12th International Conference of the African Association for Biological Nitrogen Fixation. Berlin/Heidelberg: Springer Science and Business Media BV; 2008. p15-17.

[238] Bourion V, Rizvi SM, Fournier S, de Larambergue H, Galmiche F, Marget P, Duc G, Burstin J. Genetic Dissection of Nitrogen Nutrition in Pea Through a QTL Approach of Root, Nodule, and Shoot Variability. Theor Appl Genet 2010;121(1): 71-86.

[239] Tominaga A, Gondo T, Akashi R, Zheng SH, Arima S, Suzuki A. Quantitative Trait Locus Analysis of Symbiotic Nitrogen Fixation Activity in the Model Legume Lotus japonicus. J Plant Res 2012;125(3): 395-406. 
